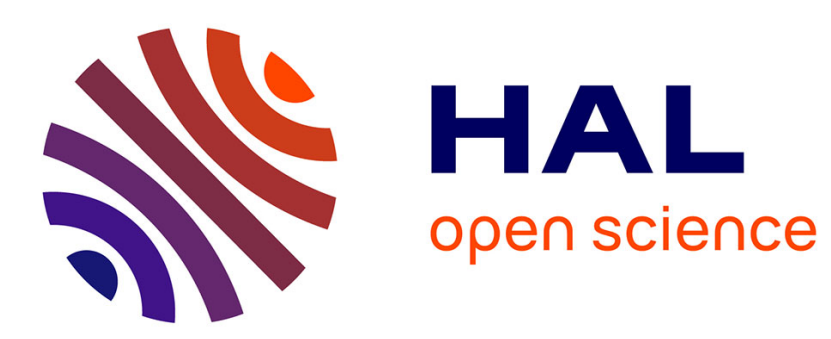

\title{
Self-Potential Tomography of a Deep-Sea Polymetallic Sulfide Deposit on Southwest Indian Ridge
}

Z Zhu, C Tao, J Shen, A Revil, X Deng, S Liao, J Zhou, W Wang, Z Nie, J Yu

\section{To cite this version:}

Z Zhu, C Tao, J Shen, A Revil, X Deng, et al.. Self-Potential Tomography of a Deep-Sea Polymetallic Sulfide Deposit on Southwest Indian Ridge. Journal of Geophysical Research : Solid Earth, 2020, 125, 10.1029/2020jb019738 . hal-03005816

\section{HAL Id: hal-03005816 https://hal.science/hal-03005816}

Submitted on 14 Nov 2020

HAL is a multi-disciplinary open access archive for the deposit and dissemination of scientific research documents, whether they are published or not. The documents may come from teaching and research institutions in France or abroad, or from public or private research centers.
L'archive ouverte pluridisciplinaire HAL, est destinée au dépôt et à la diffusion de documents scientifiques de niveau recherche, publiés ou non, émanant des établissements d'enseignement et de recherche français ou étrangers, des laboratoires publics ou privés. 


\section{JGR Solid Earth}

\section{RESEARCH ARTICLE 10.1029/2020JB019738 \\ Self-Potential Tomography of a Deep-Sea Polymetallic Sulfide Deposit on Southwest Indian Ridge}

Key Points:

- Seafloor sulfide deposits exhibit negative self-potential anomalies

- The self-potential mechanism results from redox processes

- Extend of sulfide body at depth is characterized using self-potential tomography

Correspondence to:

C. Tao,

taochunhuimail@163.com

Citation:

Zhu, Z., Tao, C., Shen, J., Revil, A., Deng, X., Liao, S., et al. (2020).

Self-potential tomography of a deep-sea polymetallic sulfide deposit on Southwest Indian Ridge. Journal of Geophysical Research: Solid Earth, 125 , e2020JB019738. https://doi.org/ 10.1029/2020JB019738

Received 8 APR 2020 Accepted 3 SEP 2020

Accepted article online 12 OCT 2020

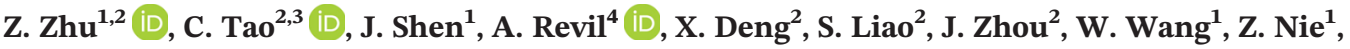 \\ and $\mathrm{J} . \mathrm{Yu}^{5}$ \\ ${ }^{1}$ State Key Laboratory of Petroleum Resources and Prospecting, China University of Petroleum (Beijing), Beijing, China, \\ ${ }^{2}$ Key Laboratory of Submarine Geosciences, Second Institute of Oceanography, MNR, Hangzhou, China, ${ }^{3}$ School of \\ Oceanography, Shanghai Jiaotong University, Shanghai, China, ${ }^{4}$ Université Grenoble Alpes, Université Savoie \\ Mont-Blanc, CNRS, UMR CNRS 5204, EDYTEM, Le Bourget-du-Lac, France, ${ }^{5}$ Ocean College, Zhejiang University, \\ Zhoushan, China
}

\begin{abstract}
Deep-sea polymetallic sulfides associated with hydrothermal systems are considered a potential viable resource for base and precious metals. The Southwest Indian Ridge (SWIR, Indian Ocean) hosts active and inactive hydrothermal systems. Inactive hydrothermal fields are more abundant than active fields but are difficult to remotely characterize. We report a deep-sea self-potential investigation to locate inactive ore deposits at the Yuhuang hydrothermal field on the ultraslow-spreading SWIR. A horizontal array of six nonpolarizing $\mathrm{AgCl}$ electrodes are attached to a deep-towed transient electromagnetic system to record the electrical field at a height of $40 \mathrm{~m}$ above the seafloor. The observed electrical field strength near a previously recognized sulfide deposits (verified by drilling) reaches an amplitude of $0.5 \mathrm{mV} / \mathrm{m}$. Negative self-potential anomalies $(\sim-27 \mathrm{mV})$ were observed by integrating the measured electrical field. The high electrical conductivities (up to $12 \mathrm{~S} / \mathrm{m}$ ) of sulfide samples measured in the laboratory and the oxidized sulfides recovered from the surface of the deposit suggest that the self-potential anomalies are due to sulfide mineralization and corrosion of the polymetallic sulfides. Inversion of the self-potential data reveals a localized body with a thickness of $\sim 65 \mathrm{~m}$, which is interpreted as the Yuhuang ore deposit. Our field data demonstrate that the self-potential method is a useful exploration method to identify and image seafloor massive sulfide deposits hosted in inactive hydrothermal fields at mid-ocean ridges.
\end{abstract}

\section{Introduction}

Massive sulfide deposits below the seafloor are rich in base and precious metals such as $\mathrm{Cu}, \mathrm{Zn}, \mathrm{Au}, \mathrm{and} \mathrm{Ag}$, which are considered to be an important mineral resource with economic potential (Hannington et al., 2011; Lipton, 2008). The formation of these seafloor sulfides is closely related to hydrothermal activity. Both active and inactive hydrothermal systems have been observed at the Southwest Indian Ridge (SWIR) (Liao et al., 2018; Tao et al., 2012). The density and size of ore bodies in mature (older) inactive hydrothermal fields are larger than those in younger active fields (Murton et al., 2019). However, the absence of water column anomalies (characterized by high-temperature plumes and turbidity resulting from the active hydrothermal vents) makes inactive fields difficult or impossible to detect using traditional methods.

Geophysical methods provide efficient nonintrusive approaches to detect hidden sulfide deposits. For instance, galvanometric and induction-based electromagnetic methods are broadly used in seafloor massive sulfide explorations (e.g., Ishizu et al., 2019; Müller et al., 2018, and references therein). Active source methods include induced polarization (IP), electrical conductivity tomography, the time domain electromagnetic method (TEM), and controlled source frequency domain electromagnetic method (CSEM) (Gehrmann et al., 2019; Haroon et al., 2018; Ishizu et al., 2019; Müller et al., 2018; Schwalenberg et al., 2016). Among these methods, TEM and CSEM have been quite popular since continuous measurements can be performed while the sensors are towed by a vessel. Passive source methods mainly include the self-potential and magnetic methods. The self-potential method detects natural geoelectrical fields associated with a source current density at depth (Jones, 1999; Revil \& Jardani, 2013). The corresponding measurement system is simple, flexible and consisting of nonpolarizing electrodes and a voltmeter. It can be mounted on a mobile platform such as that used for transient electromagnetic apparatuses or autonomous underwater vehicles. If such approach
(C)2020. American Geophysical Union. All Rights Reserved. 
appears to be efficient and cost-effective, it could provide complementary information to the active electromagnetic methods, which could be the basis for joint inversion as shown, for instance, for coal seam fire characterization (Revil et al., 2013). Indeed, electromagnetic methods can be used to detect the instantaneous electrical conductivity of ore bodies, their chargeability (associated with their polarization, Revil, Abdel, et al., 2015; Revil, Florsch, \& Mao, 2015), and a cross-gradient joint inversion followed by a semblance analysis could be used to better locate such targets thanks to the different spatial sensitivities of these methods.

Previous researchers have already made successful attempts to perform marine self-potential observations. The self-potential method was therefore qualitatively applied to the detection of seafloor massive sulfide deposits. For instance, Corwin (1976) used a pair of horizontal electrodes, that were surface-towed in $12 \mathrm{~m}$ deep water to detect a self-potential gradient anomaly of $1.2 \mathrm{mV} / \mathrm{m}$ above a known offshore mineralized area. Von Herzen et al. (1996) used the "Alvin" human occupied vehicle (HOV) to observe the vertical component of self-potential signals at the TAG active hydrothermal field located on the mid-Atlantic Ridge. They obtained a self-potential gradient anomaly of approximately $1.7 \mathrm{mV} / \mathrm{m}$ above the TAG mound, which was the first successful application of the marine self-potential method to a seafloor massive sulfide deposit. Heinson et al. (2005) performed a horizontal array observation (with three pairs of electrodes) on the continental shelf of South Australia at a water depth of less than $100 \mathrm{~m}$ with the purpose of developing a cost-efficient approach for offshore mineral exploration. They detected a self-potential gradient anomaly of approximately $0.1 \mathrm{mV} / \mathrm{m}$ at the offshore extension of a graphitic body. Kawada and Kasaya (2017) mounted a similar observation device behind a deep towed system in an active hydrothermal area in the Okinawa Trough (with a water depth of approximately 1,500 m) in Japan. He detected a self-potential gradient anomaly of $0.2-3 \mathrm{mV} / \mathrm{m}$ above the active hydrothermal vent. Beltenev and coworkers performed a series of vertical gradient potential observations in active hydrothermal fields along the mid-Atlantic Ridge (Beltenev et al., 2008). Cherkashov et al. (2010) discovered a sulfide mineralization area in the inactive hydrothermal field on mid-Atlantic Ridge using the self-potential method. Finally, Safipour et al. (2017) performed horizontal orthogonal gradient potential detection above buried sulfide ore in the Tyrrhenian Sea and detected a self-potential gradient anomaly of 1-3 $\mathrm{mV} / \mathrm{m}$ near a sulfide deposit known from drilling. However, all these observations have remained qualitative.

In recent years, the exploration for seafloor massive sulfides has entered the stage of resource evaluation. In this context, self-potential instruments can be easily mounted on AUVs (Autonomous Underwater Vehicles) for detailed exploration (Constable et al., 2018; Kawada \& Kasaya, 2018; Sato et al., 2017) and the resulting data can be treated quantitatively using self-potential tomography (Revil \& Jardani, 2013). First, compared with the towed configuration, the AUV operates at a greater height from the seafloor, about $70 \mathrm{~m}$ (Constable et al., 2018), and the self-potential gradient anomaly above the hydrothermal field is approximately 0.03 to $0.3 \mathrm{mV} / \mathrm{m}$. In the last decade, great progress has been made in self-potential tomography in the realm of hydrogeophysics (e.g., Haas et al., 2013; Karaoulis et al., 2014; Revil \& Jardani, 2013) in order to analyze the self-potential field in terms of causative source current density distribution to detect, for instance, metallic bodies (Rittgers et al., 2013). In essence, self-potential tomography is similar to what is done in the realm of electroencephalography in which the source current density is produced at the synapses between the neurons (Grech et al., 2008). The self-potential tomographic problem is posed as follows: Given a direct current (DC) conductivity distribution and using self-potential measurements recorded over a conductive material, what 3-D distribution of the source current density in the material is capable of reproducing the measurements? In the present study we use these developments to better locate the causative (source) current density of the self-potential anomalies observed in the vicinity of the seafloor.

Making observations based on the natural self-potential method is known to be simple, requiring only nonpolarizing electrodes and a sensitive voltmeter. That said, due to the rugged terrain of the hydrothermal field and deep ocean currents, precise self-potential measurements may be difficult to perform because of the navigation stability of the observation device. In our case, we added nonpolarizing electrodes to a double-tow transient electromagnetic system to improve the navigation stability of the observation configuration. To verify the effectiveness of the new configuration, two self-potential survey lines were conducted at the Yuhuang inactive hydrothermal field on SWIR, during the 49th cruise of the China Ocean Mineral Resources R \& D Association (COMRA). Here, we report the results of these two profiles and we combine 

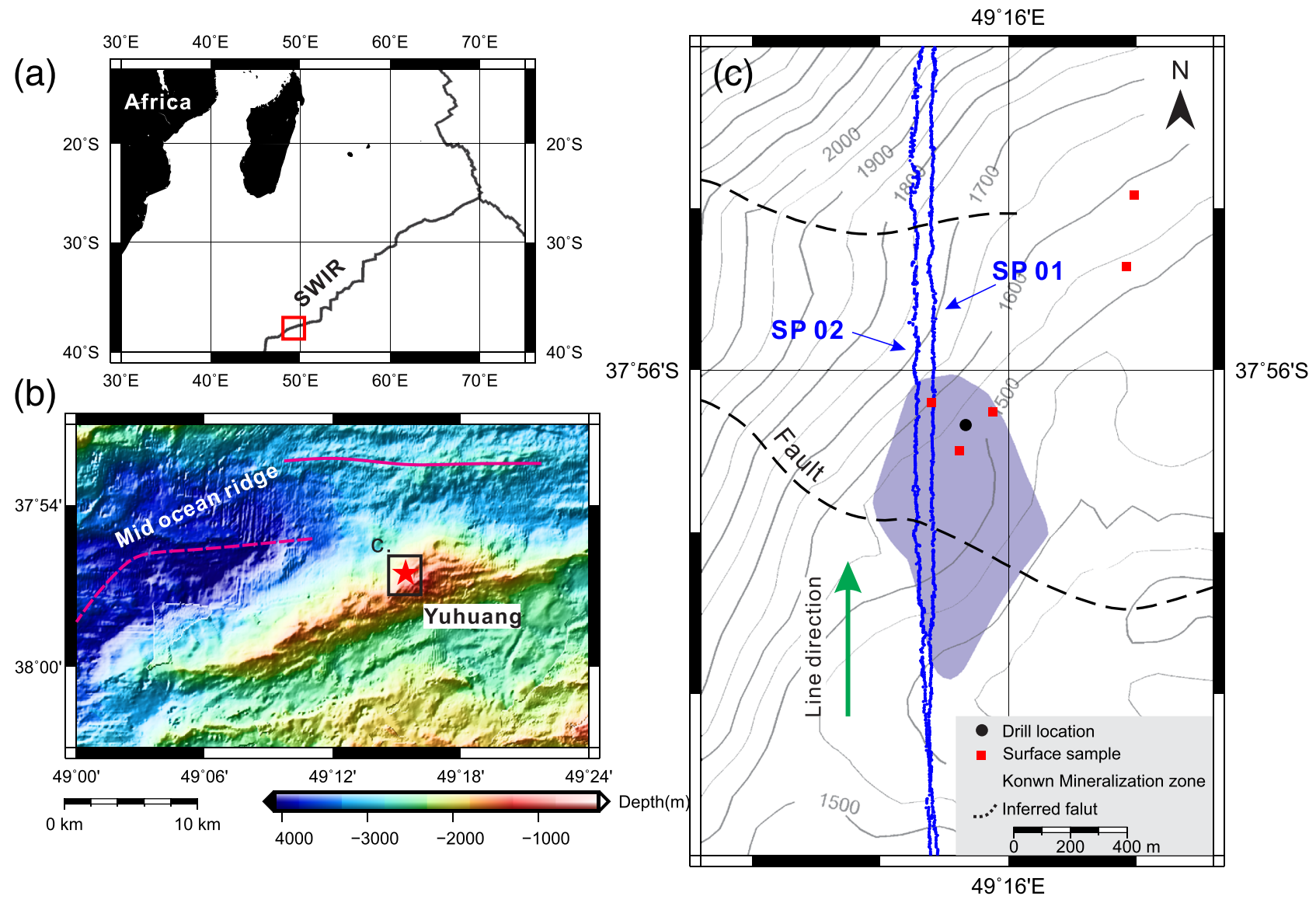

Figure 1. (a) Bathymetry map of the Yuhuang inactive hydrothermal field and locations of self-potential survey lines. (b) Regional map showing the location of the Yuhuang seamount (indicated by red star) at SWIR. (c) Dive tracks of the two survey lines: Sp01 (eastern line) and Sp02 (western line), both two survey lines are performed from south to north. The known mineralized zone is recognized through deep-tow video observations. Faults are inferred from bathymetry.

outcrop observations, rock physics and 3-D source density reconstruction obtained from the inversion of the self-potential data to better characterize the ore. Our goal is also to obtain a deeper understanding of the causative self-potential mechanism for inactive hydrothermal field on SWIR and to demonstrate the effectiveness of self-potential tomography.

\section{Geology of Study Area}

The study area corresponds to the Yuhuang seamount on the ultraslow-spreading SWIR. This test site is located at $49.26^{\circ} \mathrm{E}, 37.95^{\circ} \mathrm{S}$, with a water depth of approximately $1,500 \mathrm{~m}$. The associated inactive hydrothermal field is located on the south flank of the ocean ridge, $\sim 7.5 \mathrm{~km}$ from the midridge axis (Figure 1b). Two sulfide deposits with diameters of approximately $500 \mathrm{~m}$ were previously recognized on the northwestern slope of the Yuhuang seamount (Liao et al., 2018). Deep-towed video observations reveal the presence of these two sulfide deposits. The surface of the Yuhuang seamount is mainly composed of weathered sulfide talus, variably covered by pelagic or hydrothermal sediment. The host rock of these deposits is basalt. Several sulfide-bearing samples, including relict chimneys and sulfide breccia, have been recovered from the Yuhuang seamount by television grab (TVG). High-resolution bathymetric, magnetic, and water chemistry data have been acquired by an AUV. No plume chemistry anomalies have been discovered, suggesting that the hydrothermal field is likely inactive. Drilling of the Yuhuang seamount revealed that sulfide rich samples are covered by $50 \mathrm{~cm}$ of calcareous sediments. Unfortunately, the well ( $8 \mathrm{~m}$ in length) did not penetrate the bottom of the sulfide ore bodies and its thickness is therefore unknown (Liao et al., 2018). For all these reasons, the seamount was chosen as a suitable target to test the ability of the self-potential tomographic method to characterize such buried massive sulfide deposits. 


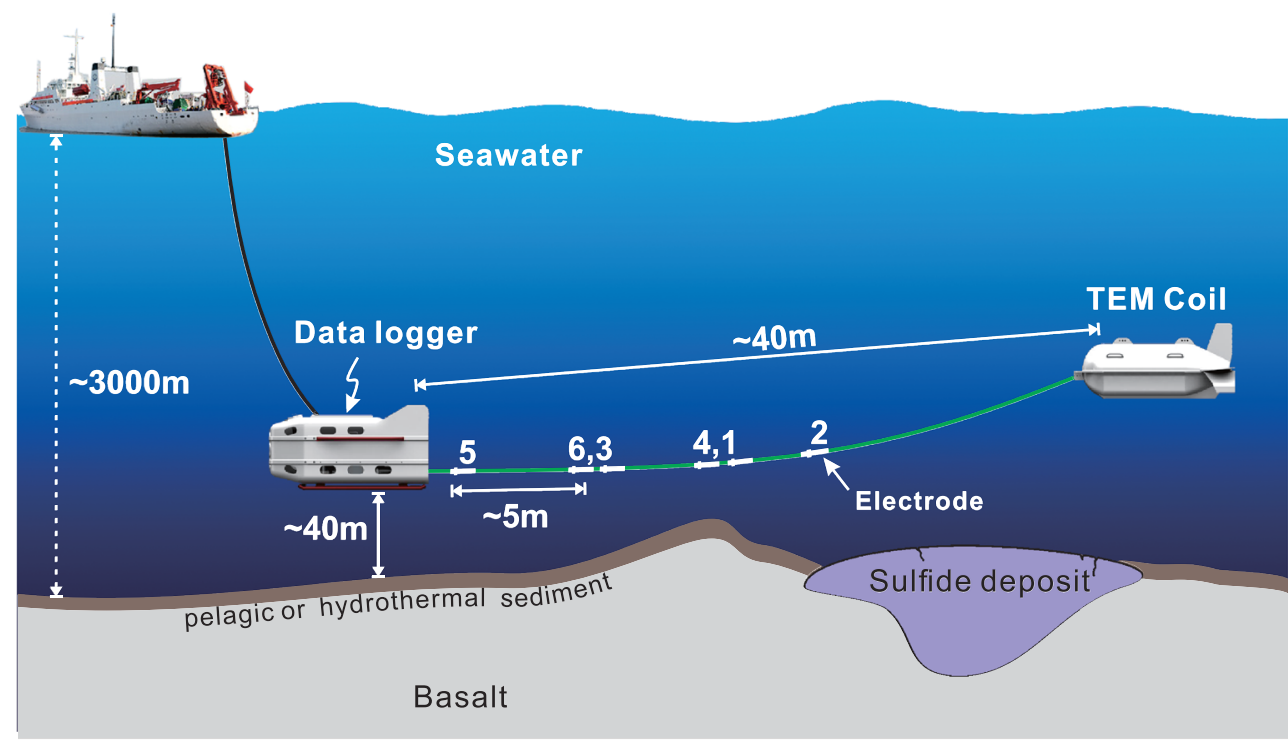

Figure 2. Sketch of the deep-towed self-potential instrument. Configuration of the present survey with an $\sim 15 \mathrm{~m}$ long electrode array. Green line denotes the cable links control terminal and TEM coil. The numbers on the cable show locations of $6 \mathrm{Ag} / \mathrm{AgCl}$ electrodes. The data logger is mounted inside of the control terminal.

\section{Instrumentation}

The navigation stability of the nonpolarizing electrode configuration is very important for a marine self-potential survey. We first positioned the electrodes behind the deep-towed camera with a soft cable. Such a configuration appears to be unsuitable when the topography changes greatly. The self-potential system used in this study was mounted on a double-tow transient electromagnetic system. The system consists of two plastic fiber tow bodies (see details in Figure 2). The front tow contains the control electronics and power units, which connect to the ship by communication cable. For TEM measurements, an in-loop configuration, with a transmitter, receiving loops and floating balls, is packaged in the tail tow. The total weight of the system is $\sim 260 \mathrm{~kg}$. The front and tail tows communicate through a hard trunk cable of approximately $40 \mathrm{~m}$ (Figure 2). The tail of the TEM system is designed to have an upward buoyancy, and the trunk cable is horizontal or slightly upward sloping at $\sim 2-3^{\circ}$ when the system is towed at a constant speed. This nearly horizontal and relatively stable trunk cable provides a stable platform for the nonpolarizing electrodes used to carry out the self-potential survey.

To minimize possible spurious effects of the TEM equipment on self-potential data, $\mathrm{Ag}$ - $\mathrm{AgCl}$ nonpolarizing electrodes (Chen et al., 2018) are attached far from the TEM transmitters. Here, we use a set of electrode pairs since the recorded static electrical field is multicomponent by nature (Constable et al., 2018; Safipour et al., 2017). Therefore, three pairs of electrodes $\left(\varphi_{1}, \varphi_{2}, \varphi_{3}, \varphi_{4}, \varphi_{5}, \varphi_{6}\right)$ are attached to the trunk cable to measure the potential differences $\varphi_{12}\left(=\varphi_{1}-\varphi_{2}\right), \varphi_{34}\left(=\varphi_{3}-\varphi_{4}\right)$ and $\varphi_{56}\left(=\varphi_{5}-\varphi_{6}\right)($ see Figure 2). We choose the vessel's sailing direction as the positive direction of the electrical field. To detect stronger self-potential signals, a separation between the electrodes of approximately $5 \mathrm{~m}$ is used based on a sensitivity analysis and the typical electrical fields recorded in marine environments over sulfide deposits.

The front tow of the system is equipped with an altimeter with a range of $200 \mathrm{~m}$, and the height of the system is adjusted during operation by the winch. The system's status data and acquisition data are uploaded to the deck monitoring system via a fiber optic cable. Ultrashort baseline (USBL) acoustics are used to achieve underwater positioning.

\section{Data Acquisition and Processing}

\subsection{Data Collection and Acquisition}

Two self-potential survey lines were carried out during Research Cruise DY49IV (2018.05.04-2018.06.20). Self-potential data were collected for over $18 \mathrm{hr}$ : SP01 was towed from south to north. Since the 

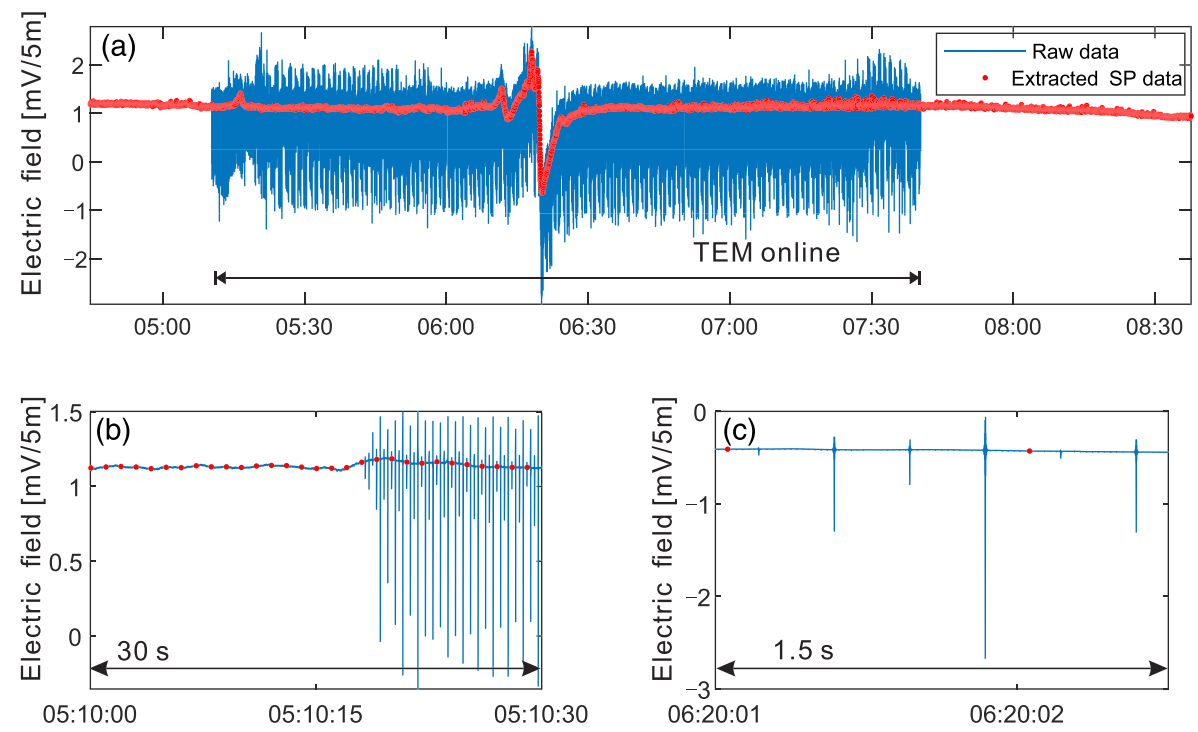

Figure 3. Measured times series data of electrical field. (a) Raw continuous time series data of electrical field with sampling rate of 2,400 Hz, (b) local enlarged $30 \mathrm{~s}$ time series when TEM turned on, and (c) raw data in $1.5 \mathrm{~s}$ length. Red dots are extracted self-potential signal when TEM current is turned off. TEM stands for transient electromagnetic.

dual-towed system could not change its direction in the ocean, the system was recovered back to deck after $6 \mathrm{hr}$ of survey, and then the ship returned to the start point to conduct SP02. The two survey lines were both towed along south-north profile with a parallel separation of $100 \mathrm{~m}$ (see Figure 1c). Each survey was completed in three phases: descent, seafloor detection, and ascent. During the process of descent and ascent, the system measured background fields at different seawater depths to correct the difference between electrode pairs and temporal electrode drift. When approaching the seafloor, the apparatus was towed at a speed of $0.8 \mathrm{~m} / \mathrm{s}$ and an average height of $40 \mathrm{~m}$ above the seafloor to measure the electrical fields related to the near seafloor target. Six-channels DC electrical field data were sampled at 2,400 $\mathrm{Hz}$. GPS time was synchronized before each deployment to track the position of the system via USBL, and the sampling rate of USBL is $5 \mathrm{~s}$.

\subsection{Data Processing}

Electrical fields are obtained by dividing the measured voltage by the electrode distance (approximately $5 \mathrm{~m}$ as explained above). The raw sample frequency $(2,400 \mathrm{~Hz})$ is too high for the DC component and records the secondary electrical field induced by the TEM transmitter, which is regarded as noise for self-potential surveys (Figure 3a). When the TEM transmitter was turned on, a bipolar current waveform with a $50 \%$ duty cycle, a current amplitude of $20 \mathrm{~A}$ and a repetition frequency of $1 \mathrm{~Hz}$ was transmitted through the transmitter loop. In one cycle of TEM measurement, the induced electrical field lasted only a very short time just after the current was switched on or off (Figures $3 b$ and 3c), and there was no primary electrical field generated by a loop source. It is therefore possible to extract the natural electrical field from the raw time series. Measurement data at $0.15 \mathrm{~s}$ after each current step were extracted as the natural electric field (see Figure 3c). Consistent data are obtained by filtering or resampling.

The self-potential results of all three pairs of electrodes are shown in Figure 4. A least squares smoothing filter specifying a polynomial order of 2 and a window length of $30 \mathrm{~s}$ is applied to smooth the signal. However, $E_{12}$ includes more noise than $E_{34}$ and $E_{56}$, because $E_{12}$ is close to the center of the cable and its attitude is more sensitive to the change in system height as the winch adjusts the system altitude above the seafloor. In addition, the TEM measurements have a great influence on the electrode $\mathrm{E}_{12}$, and the electrodes are closer to the transmitting coil, which introduce induction noise owing to transient current in the coil. There are also spurious pulse-type signals caused by the system colliding with the seafloor. These specific events could be distinguished by sudden changes of the altimeter. The processing flow is summarized in Figure 4. 

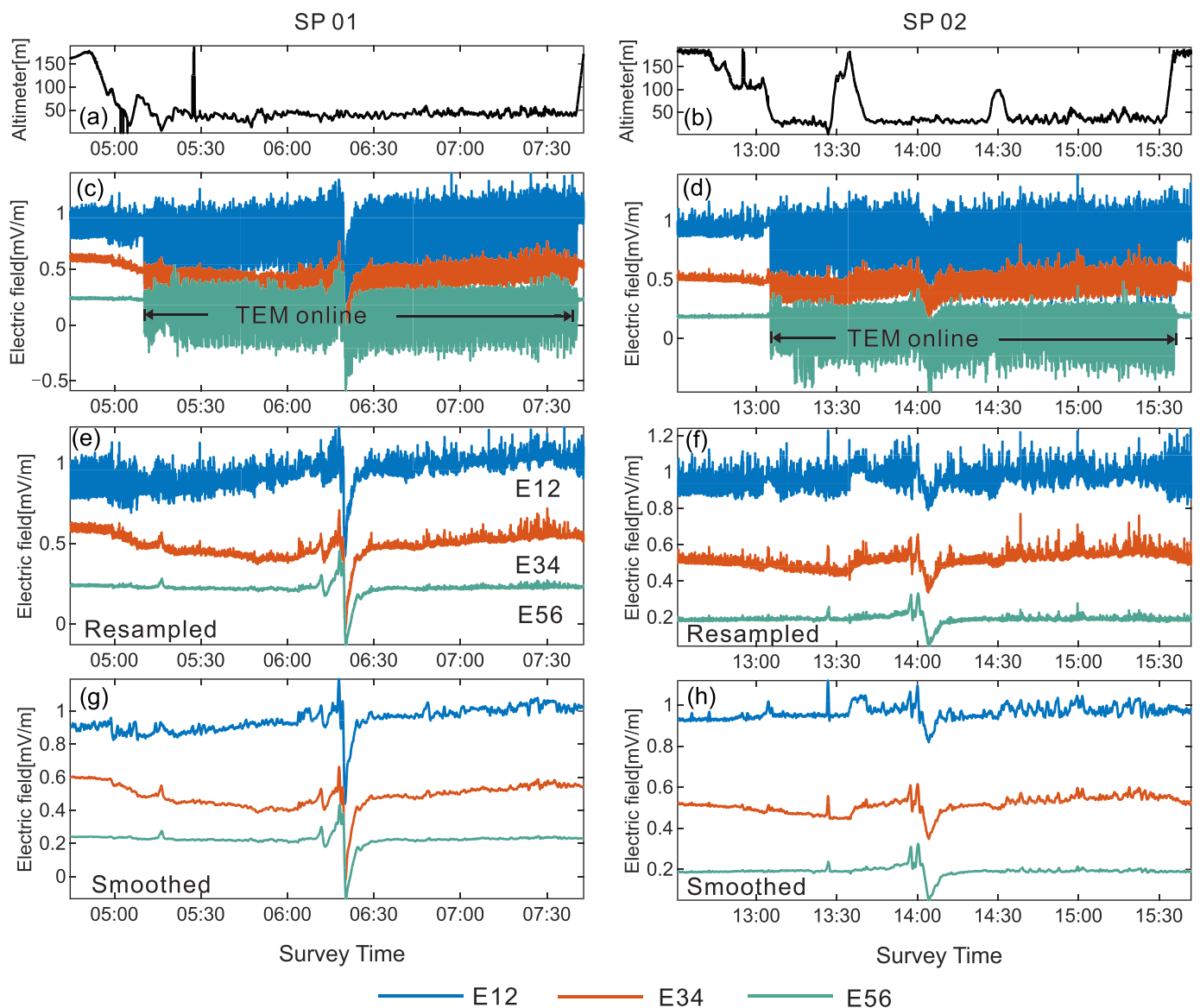

Figure 4. Raw and processed observation results. $E_{12}, E_{34}$, and $E_{56}$ correspond to pairs of 12,34 , and 56 electrodes (a and b) Altitude of system above seafloor. (c and d) Original continuous time series electrical field data at $2400 \mathrm{~Hz}$; (e and f) resampled electrical field data at $1 \mathrm{~Hz}$; ( $\mathrm{g}$ and $\mathrm{h}$ ) smoothed electrical field data with time window of $30 \mathrm{~s}$.

Other artifacts can be associated with the nonpolarizing electrodes themselves, which have an inner potential that is temperature and time dependent. The average temperature measured in situ is approximately $3.3^{\circ} \mathrm{C}$, and the variation is less than $\pm 1^{\circ} \mathrm{C}$. A temperature correction is applied with a temperature coefficient of $0.3 \mathrm{mV} /{ }^{\circ} \mathrm{C}$. After temperature correction, a time-varying electrode drift curve was calculated by fitting a linear trend through the control points when the system was high during the beginning and end of each profile, and consequently subtracted from the data (see Revil \& Jardani, 2013). Compared to the effect of a moving cable and related geometrical uncertainty of the electrodes, the spurious electrical field associated with the ambient geomagnetic field can be ignored. Raw data are filtered, detrended, and shifted in a way that the electrical potential at the beginning of each profile is equal to 0 (see Figures $5 \mathrm{c}$ and $5 \mathrm{~d}$ ).

\subsection{Data Analysis}

Through preliminary preprocessing, the self-potential anomalies related to near the seafloor of two surveys SP01 and SP02 are shown in Figures 5c and 5d. The electrical fields recorded by the three pairs of electrodes show good consistency. Only component $\mathrm{E}_{56}$ is therefore displayed here.

In the present study, the deep-tow altitude varies from 30 to $50 \mathrm{~m}$, keeping the average survey height approximately $40 \mathrm{~m}$ (Figures 5a and 5b). The two survey lines consistently reveal how the electrical field is distorted and its magnitude increases above the sulfide deposit $(x \sim 0$ corresponds to the central position of the Yuhuang hydrothermal deposit). The main trends are consistent, indicating that the causative source of the observed anomalies could be from the same origin. The major electrical field anomaly in SP01 extends to approximately $80 \mathrm{~m}$ from maximum to minimum peaks, with a magnitude of about $0.55 \mathrm{mV} / \mathrm{m}$. The western survey line SP02 exhibits a similar feature compared to SP01, but with a smoother change in the 

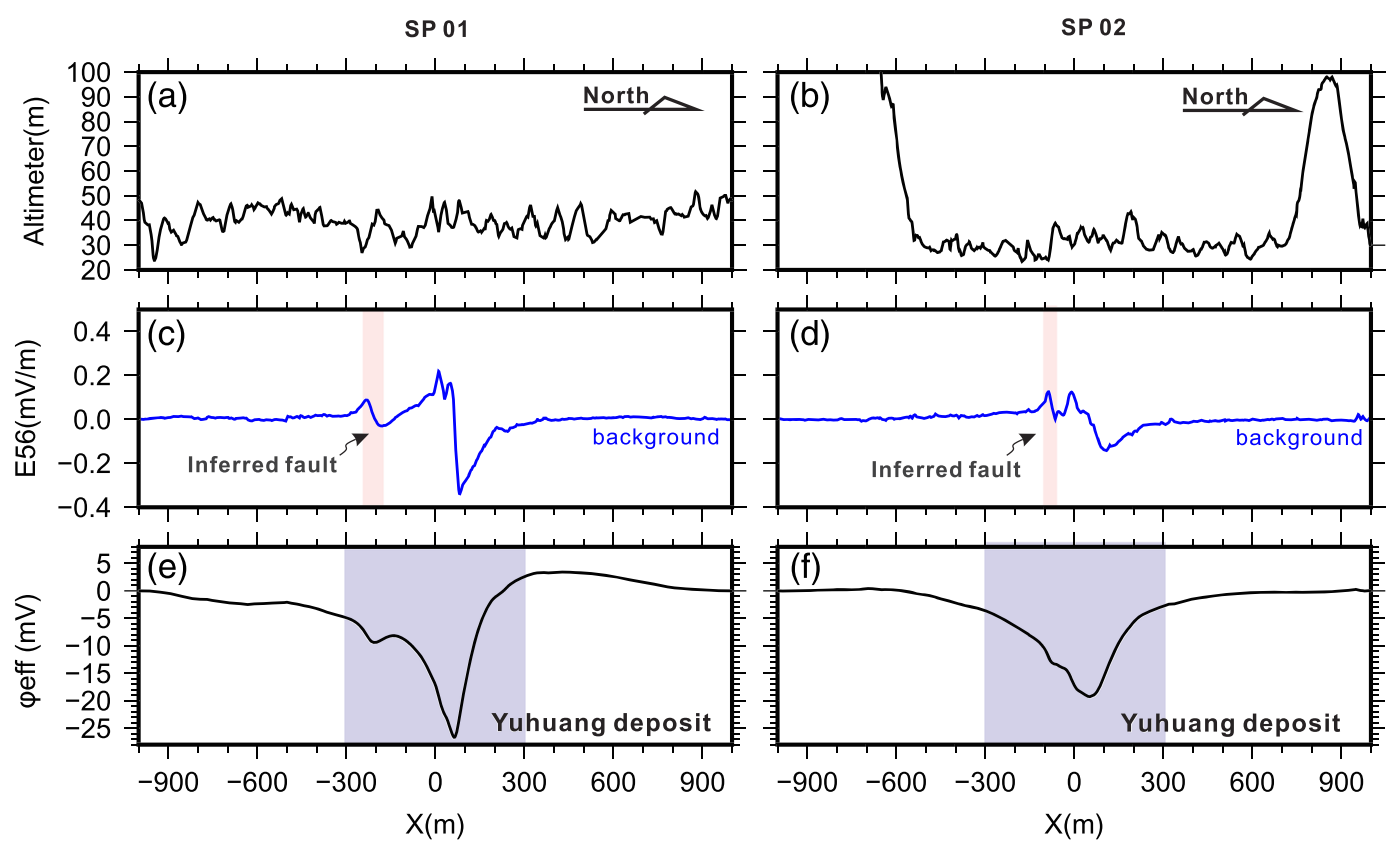

Figure 5. Electrical field and electrical potential along profiles. (a and b) The system altitude above seafloor. (c and d) The electrical fields after shifting, pink rectangle denotes the location of fault inferred from bathymetry. (e and f) The magnitudes of the effective electrical potential $\varphi_{\text {eff. }}$. The purple rectangle denotes the extent of the Yuhuang deposit, which is recognized by video surveying.

gradient. Some short-wavelength anomalies of $\sim 0.12 \mathrm{mV} / \mathrm{m}$ are also observed in the southern portion of the profiles (at approximately $-200 \mathrm{~m}$ on SP01 and $100 \mathrm{~m}$ on SP02). These anomalies are well matched with a NW-NE trending fault that crosses the hydrothermal field, as inferred from bathymetry (Figure 1c).

In the case of mineral exploration, the self-potential anomaly is usually expressed by the electrical potential $\varphi$ (in V). We can convert the measured horizontal electrical field along the direction of the survey line to the effective potential $\varphi_{\text {eff }}$, by integrating the electrical field:

$$
\begin{gathered}
\frac{d \varphi_{\text {eff }}}{d x}=-E_{x} \cong-\frac{\varphi_{2}-\varphi_{1}}{\Delta x}=\frac{\varphi_{1}-\varphi_{2}}{\Delta x}, \\
\varphi_{\text {eff }}=\varphi_{\text {start }}+\int_{x, \text { start }}^{x, \text { end }} E_{x} d x
\end{gathered}
$$

where $\Delta x$ denotes the spacing between the nonpolarizing electrodes and $x_{\text {end }}$ and $x_{\text {start }}$ denote the starting and endpoints of each survey. Before performing the numerical integration corresponding to Equation $1 \mathrm{~b}$, the electrical fields are interpolated onto a regular grid with an interval of $1 \mathrm{~m}$ along the two-survey lines. We use the notation $\varphi_{\text {eff }}$ to indicate that the potential distribution is here refers to a common point (considered to be the reference station, see Revil \& Jardani, 2013) at the beginning of the profile (zero potential).

Figures $5 \mathrm{e}$ and $5 \mathrm{f}$ show the effective potential derived from the horizontal electrical field within $1 \mathrm{~km}$ around the hydrothermal site, and the origin point is chosen near the center of the Yuhuang deposit. A negative self-potential anomaly that is $600 \mathrm{~m}$ wide is identified at the center of each survey line. The minimum potential is close to $-27 \mathrm{mV}$. This is a strong anomaly when considering the high conductivity of the seawater (approximately $3.2 \mathrm{~S} / \mathrm{m}$ ) and the resulting damping of the electric signal.

\section{Self-Potential Tomography}

\subsection{The Causative Source of the Negative Self-Potential Anomalies}

In this section, we first discuss the origin of the source current density we want to analyze. In marine environments, significant self-potential anomalies are related to mineral deposits. That said, hydrothermal 
circulation beneath the seafloor and hydrothermal fluid discharge from active vents can also produce self-potential anomalies of an electrokinetic nature (see, for instance, Cumella et al., 2017, for sedimentary basins; Ishido \& Mizutani, 1981, for laboratory measurements; and Richards et al., 2010 for hydrothermal systems). To explain the occurrence of negative self-potential anomalies over sulfide deposits, a geobattery model was developed by Sato and Mooney (1960) (see also Naudet \& Revil, 2005; Rittgers et al., 2013). In this model, the ore body connects domains of different redox potentials and acts as a conducting pathway allowing electron transfer from the reduced part at depth to the oxidized seafloor. Self-potential anomalies generated by the geobattery mechanism are expected to be dipolar in nature and associated with the distribution of the redox potential at depth (e.g., Rittgers et al., 2013). In this respect, Yamamoto et al. (2018) observed that at an active vent characterized by the presence of high-temperature hydrothermal fluids, the redox potential of the deposits in the vicinity of the vent is more negative than that in the ambient seawater owing to the presence of strongly reducing hydrothermal fluids. The self-potential signals associated with ore deposits are generally much stronger than the electrokinetic anomalies associated with ground water flow (e.g., Kawada \& Kasaya, 2018; Revil et al., 2012).

The distinct negative self-potential anomalies observed at the Yuhuang seamount are more likely related to the inactive sulfide deposit rather than the electrokinetic effects of an active vent. Indeed, no water plume (temperature/turbidity) anomalies related to the active vent were detected while several sulfide samples were recovered by television grab (TVG) and drilling in the vicinity of the negative self-potential anomaly. Mounds containing sulfide products were drilled close to the eastern side of self-potential anomalies (Figure 6a). A layer of massive sulfide starting at $1 \mathrm{~m}$ below seafloor has been recovered from site MD04 to the northeast of the self-potential anomalies (Figure 6a). Drilling at site MD04 revealed that the uppermost layer comprises pelagic calcareous sediments, up to $0.15 \mathrm{~m}$, underlain by $0.4 \mathrm{~m}$ of black-colored, unconsolidated hydrothermal sediments derived from the weathering of relict chimney fragments. A layer of at least $4.6 \mathrm{~m}$ of massive sulfides occurs beneath the shallow sediments. The sulfides are dominated by chalcopyrite and pyrite, with high copper concentrations of up to $20 \mathrm{wt} . \%$. Video observations show sulfide outcrops exposed on the summit of older mounds, surrounded by red brown oxidized iron-rich hydrothermal sediment and pelagic sediments (Figure 6c). The corrosion of iron-rich sulfide in the formation of limonite is also recovered at site TVG22 by television grab (as shown in Figure 6d). The oxidized crust dominantly comprises $\mathrm{Fe}(\mathrm{OH})_{3}$, which is an oxidation precipitation product produced when surface iron-rich sulfides are exposed to neutral oxygenated seawater.

To characterize the electrical conductivity of SMS deposits, conductivity measurements were conducted in the laboratory with six SMS samples. These samples were collected along the seafloor by the TVG from hydrothermal fields in the SWIR (see Table 1). Observations of the samples under microscope reveal that the outcrop sulfides predominantly contain pyrite $\left(\mathrm{FeS}_{2}\right)$, chalcopyrite $\left(\mathrm{CuFeS}_{2}\right)$, and sphalerite $(\mathrm{ZnS})$, with ferric hydroxides identified at the surface of SMS samples. High conductivities (up to $12 \mathrm{~S} / \mathrm{m}$ ) have been measured in Fe-rich sulfides, which are three orders of magnitude higher than the reference conductivity of basaltic core samples collected from outcrops. Many of SMS samples have high conductivities, which cannot be explained by electrolytic conductivity including bulk conductivity through the pore space (Archie, 1942) and surface conductivity associated with alteration and cation exchange capacity (Revil, Qi, et al., 2019). X-ray diffraction analysis of the samples indicates that their conductivity increases with the content of $\mathrm{Fe}$ and $\mathrm{Cu}$ rich minerals, rather than the porosity of the sample. The sampled sulfide recovered from site MD04 comprises pyrite and chalcopyrite that are 4 orders of magnitude higher in Cu concentration than that of surface sulfides, suggesting a very conductive layer at shallow depths just below the seafloor. Similar pyrite samples from TAG also show high conductivities and the highest conductivity could reach 3,000 S/m (Gehrmann et al., 2019). Such high conductivity implies that the conductive minerals are physically connected (Gehrmann et al., 2019; Hördt et al., 2016). These conductive and connected sulfides provide a good channel for electron and p-hole electromigration.

Pyrite and chalcopyrite behave as semiconductors and as such are responsible for a high instantaneous conductivity (see Figure 7; Revil, Abdel, et al., 2015; Revil, Florsch, \& Mao, 2015). When short-circuited, such semiconductors are characterized by high electrical conductivities (typically in the range 1 to $10,000 \mathrm{~S} / \mathrm{m}$; see Pridmore \& Shuey, 1976). That said, the same ore embedded in sediment or a basaltic rock, would act as an insulator under DC conditions (Revil, Abdel, et al., 2015; Revil, Florsch, \& Mao, 2015) as explained 


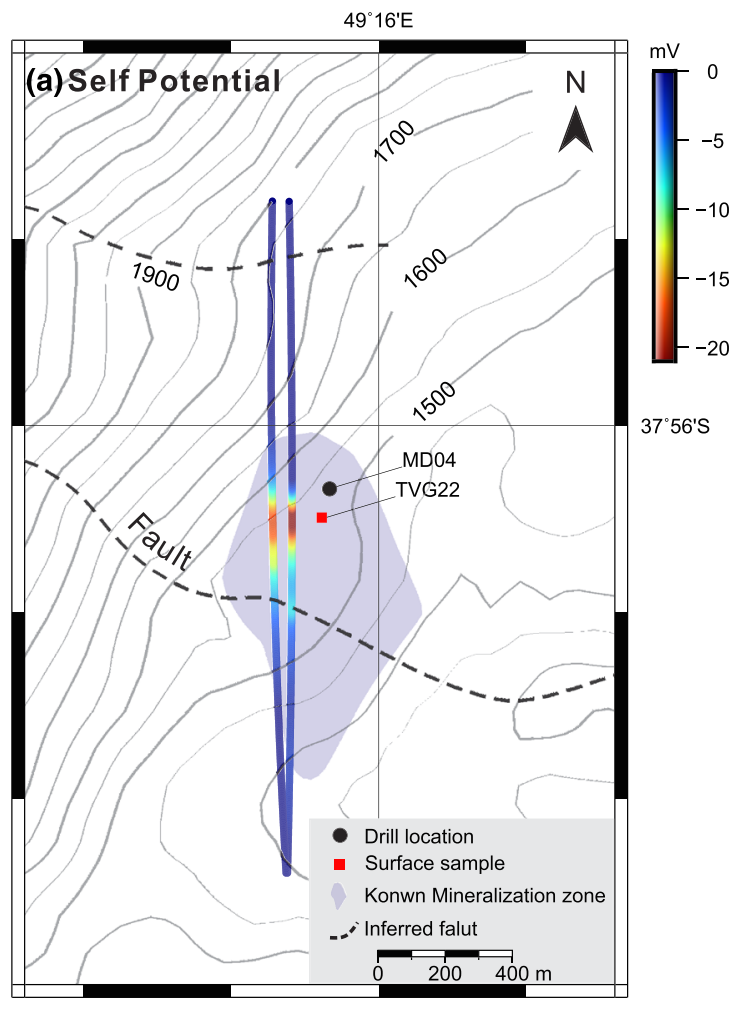

(b) Sulfide core sample from MD 04

(c) Inactive deposit

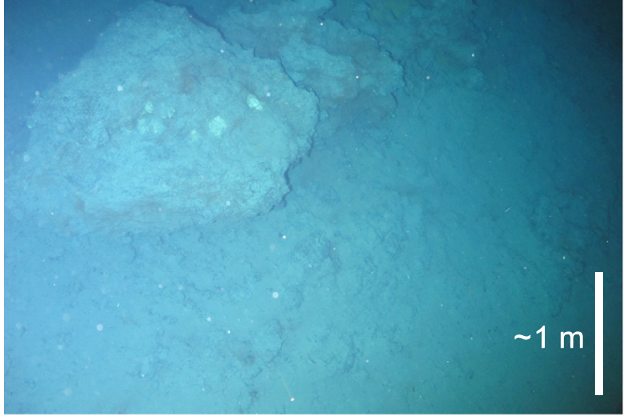

Figure 6. Distribution of the self-potential together with the material of the ore outcrop and drilling core. The drilling location containing massive sulfides is indicated by the black dot. Grabbed samples containing sulfides coated by limonite indicated by red square. Contours denote bathymetry of study area. Boundary of mineralization zone is recognized by geology video survey. (a) Magnitude of effective self-potential $\varphi_{\text {eff. }}$. (b) Massive sulfide core sample (Cu concentration up to 20\%) recovered from site MD04. (c) Photographs of inactive sulfides near self-potential survey profile SP02. (d) Ferric hydroxides recovered at site TVG22.

in Figure 8. In reality, a pyrite cube is not a perfect insulator because of the redox reactions in the redox potential field and behaves more like a leaking polarized body.

The polarization of the material shown in Figure 8 can be characterized by a property called chargeability, which can be obtained from IP measurements. It follows that IP could be an interesting complementary tool (in addition to self-potential) for further quantifying the amount of metal in these deposits (Revil, Abdel, et al., 2015; Revil, Florsch, \& Mao, 2015).

As observed sulfides formed on the seafloor are generally polymetallic, the majority of the Yuhuang deposits contain a mixture of sulfide minerals in different abundances including pyrite, chalcopyrite, secondary $\mathrm{Cu}$ sulfides (bornite), and sulfosalts. A microgalvanic cell occurs where two different sulfide minerals are in physical contact (Fallon et al., 2017). When chalcopyrite and pyrite are in contact with each other, chalcopyrite with a lower resting potential behaves as an anode and preferentially dissolves, protecting pyrite, which 
Table 1

Petrophysical and Geochemical Parameters of the Surface Core Samples

\begin{tabular}{lcccrrr}
\hline & \multicolumn{5}{c}{ Composition } & \\
\cline { 2 - 4 } Rock type & $\begin{array}{c}\mathrm{Fe}(\text { wt. } \\
\%)\end{array}$ & $\begin{array}{c}\mathrm{Cu}(\text { wt. } \\
\%)\end{array}$ & $\begin{array}{c}\mathrm{Zn}(\mathrm{wt} . \\
\%)\end{array}$ & $\begin{array}{c}\sigma(\mathrm{S} / \mathrm{m}) \\
\left(25^{\circ} \mathrm{C}\right)\end{array}$ & $\begin{array}{c}\text { Porosity } \\
\phi(\%)\end{array}$ \\
\hline Fe-rich sulfide & 29.90 & 4.42 & 2.34 & 12.03 & 8.08 \\
Fe-rich sulfide & 28.00 & 3.68 & 5.71 & 9.89 & 7.08 \\
Fe-rich sulfide & 31.89 & 2.24 & 1.93 & 1.40 & 8.21 \\
Fe-rich sulfide & 22.72 & 0.30 & 11.35 & 0.13 & 14.36 \\
Zn-rich & 7.67 & 0.08 & 9.96 & 0.11 & 13.58 \\
$\quad$ sulfide & & & & & \\
Zn-rich & 8.68 & 0.41 & 12.71 & 0.04 & 10.69 \\
$\quad$ sulfide & & & & & \\
Basalt & - & - & - & 0.01 & 1.86 \\
\hline
\end{tabular}

Note. The conductivity $\sigma(\mathrm{S} / \mathrm{m})$ is measured at a pore water conductivity of $5 \mathrm{~S} \mathrm{~m}^{-1}\left(25^{\circ} \mathrm{C}\right)$. The compositions of samples are characterized by X-ray diffraction. behaves as the cathode. Therefore, the anodic reaction at depth oxidizes the $\mathrm{S}$ (-II) in the chalcopyrite and is coupled with the release of $\mathrm{Fe}^{2+}$ and $\mathrm{Cu}^{2+}$. These species can move away from their source by electrodiffusion and fluid flow. The released electrons are transported through the conductive sulfide matrix and generate a natural electrical current flowing downward. This mechanism can be summarized by the following reactions (Figure 9). (i) The anodic reaction occurring at depth can be written as follows:

$$
\mathrm{CuFeS}_{2} \rightarrow \mathrm{Cu}^{2+}+\mathrm{Fe}^{2+}+\mathrm{S}+4 \mathrm{e}^{-}
$$

while (ii) the cathodic reactions occurring at the seafloor are

$$
\begin{gathered}
\mathrm{O}_{2}+2 \mathrm{H}_{2} \mathrm{O}+4 \mathrm{e}^{-} \rightarrow 4 \mathrm{OH}^{-} \\
4 \mathrm{OH}^{-}+2 \mathrm{Fe}^{2+} \rightarrow 2 \mathrm{Fe}(\mathrm{OH})_{2} \\
\mathrm{Fe}(\mathrm{OH})_{2}+\mathrm{OH}^{-} \rightarrow \mathrm{Fe}(\mathrm{OH})_{3}
\end{gathered}
$$

Reaction 3 corresponds to the half-reaction associated with the electrons provided by the sulfide body itself.

In addition, the presence of bacteria in sulfidic sediment can also promote charge transfer and generate natural electrical current at the millimeter scale (Nielsen et al., 2010; Revil et al., 2010). In this case, the ore deposit would serve as a conductor for the transfer of electrons in biotic reactions. We conclude that the integrated rock physics analysis together with geological phenomena, abiotic precipitation, and dissolution of sulfide minerals are likely to be the most prominent sources of the observed negative self-potential

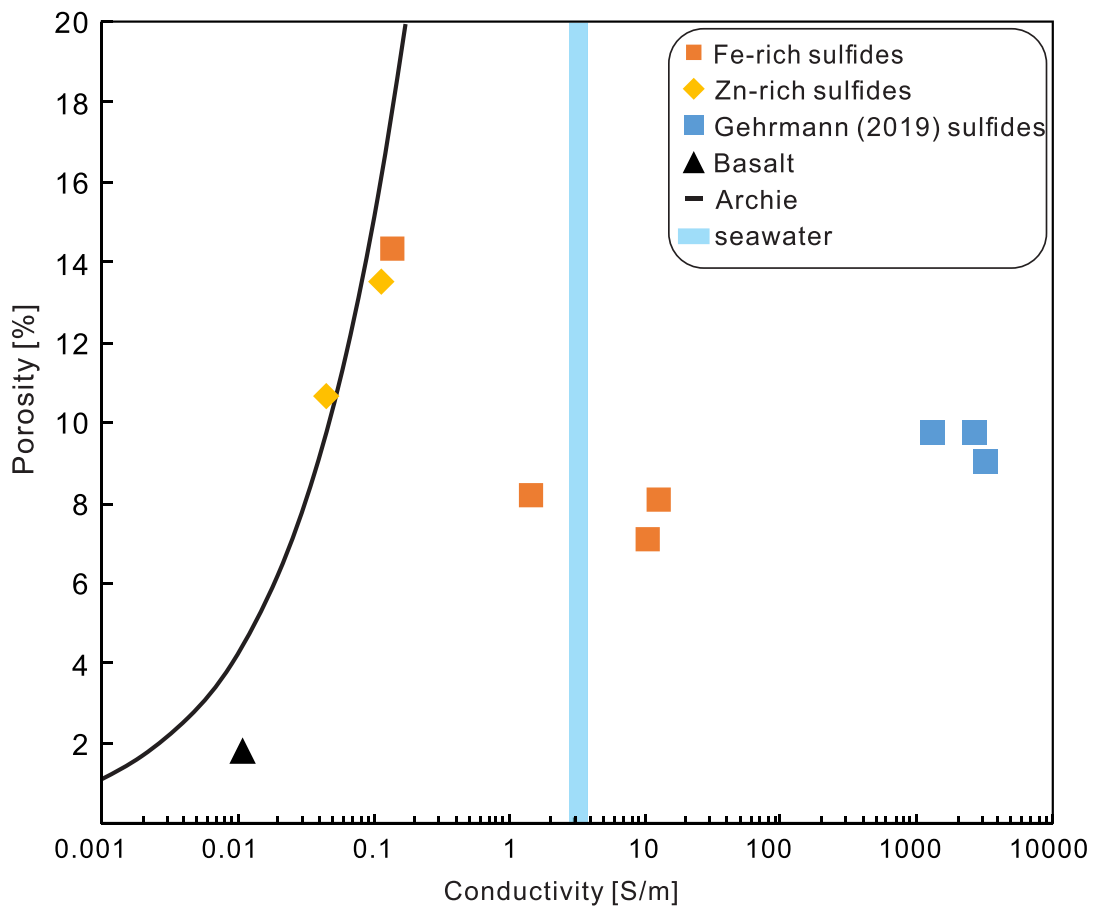

Figure 7. Porosity versus electrical conductivity of selected samples from SWIR (rectangles) and other sources (triangles); solid line represents Archie's law approximation for electrolytic conduction in fresh hard rocks (neglecting therefore surface conductivity associated with alteration) with $\sigma=\sigma_{w} \phi^{2}$ where $\sigma_{w}$ denotes the sea water conductivity of $5 \mathrm{~S} \mathrm{~m}^{-1}\left(25^{\circ} \mathrm{C}\right)$ and $\phi$ the porosity. The high conductivity of the sulfide core samples is more representative of their instantaneous conductivity and not their DC conductivity as discussed in Revil, Abdel, et al. (2015) Revil, Florsch, and Mao (2015). Indeed, the short circuiting of an ore with a continuous pyrite body does not generate any polarization like in high-frequency AC (alternating current) conditions. In DC conditions, the electrodes are however not in contact with the pyrite body, and the ore would get polarized in an external electrical field. 


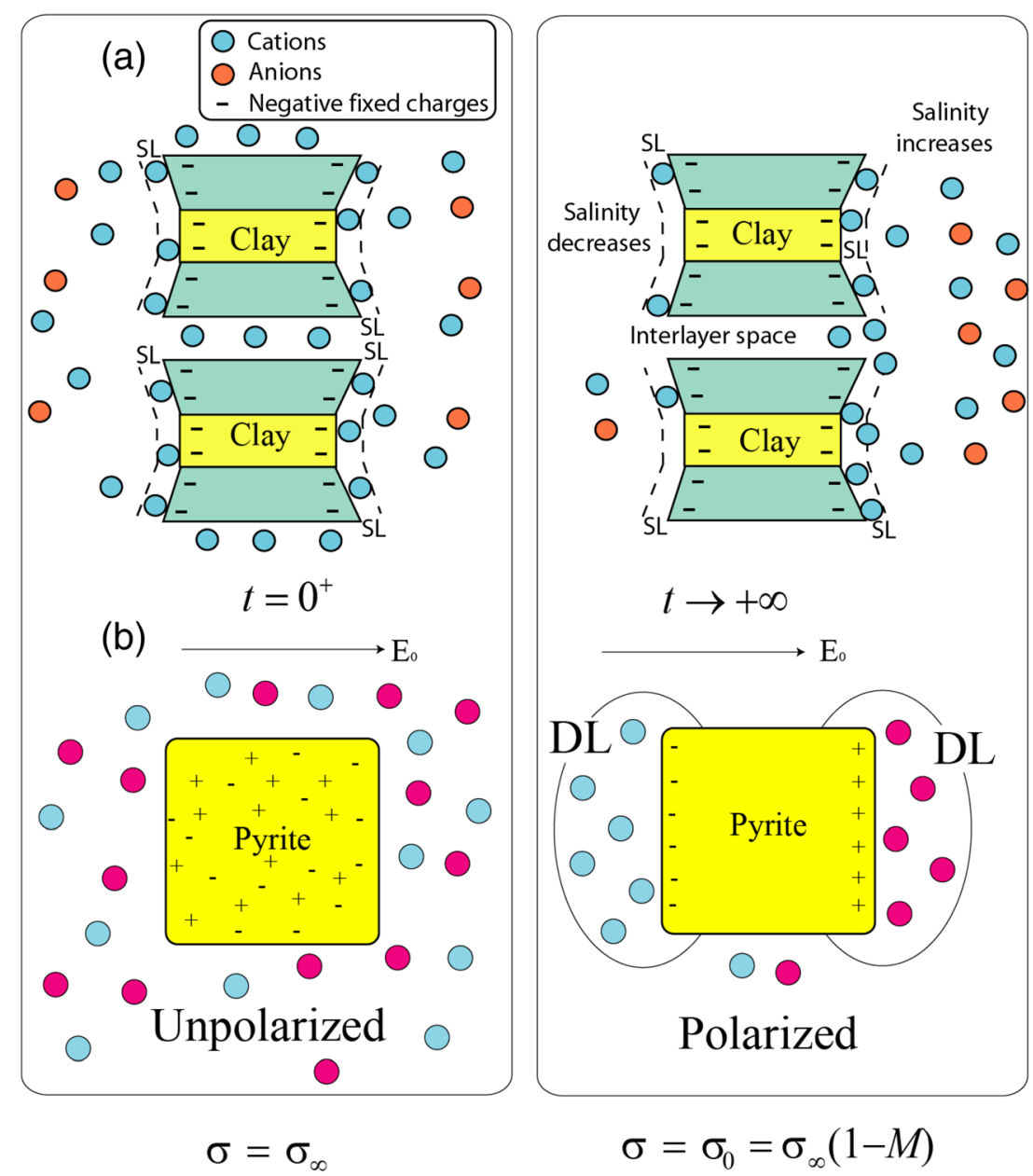

Figure 8. Sketch of the polarization of a pyrite grain and a clay particle. (a) The clay is surrounded by an electrical double layer. Under the influence of an applied electrical field $\mathbf{E}_{0}$, this electrical double layer polarizes and provides a dipole moment to the grain. (b) Polarization of a pyrite cube. Under the application of the same electrical field, electrons, and p-holes polarize the grain. The first column defines the instantaneous conductivity $\sigma_{\infty}$ while the second column defines the DC (direct current) conductivity $\sigma_{0}$ ( $M$ denotes the chargeability). The relevant conductivity for a self-potential survey is the DC conductivity. (Modified from Abdulsamad et al., 2019)

anomalies. The ore body behaves as a polarized leaking semiconductor. The tomography of the recorded self-potential signals along the two profiles is discussed in the next section.

\subsection{Inversion of Self-Potential Anomalies}

The electrical field above the Yuhuang inactive hydrothermal field exhibits a dipolar anomaly of $0.8 \mathrm{mV} / \mathrm{m}$ with a peak-to-trough distance of approximately $80 \mathrm{~m}$ at a system altitude of $40 \mathrm{~m}$. This implies a source of current located near the seafloor. To determine the distribution of SMS deposits, we perform tomography on the voltage (potential) distribution. Our goal is to determine the vertical current source density component (expressed in $\mathrm{A} / \mathrm{m}^{2}$ ) using the approach developed by Jardani et al. (2008). The forward problem of self-potential can be expressed by an elliptic partial differential equation (the Poisson equation, see Jardani et al., 2008) obtained by combining a generalized Ohm's law with the static charge conservation equation

$$
\nabla \cdot(\sigma \nabla \varphi)=\nabla \cdot \mathbf{J}_{s}
$$

where $\mathbf{J}_{S}$ denotes the source current density vector $\left(\mathrm{A} / \mathrm{m}^{2}\right), \sigma$ denotes the DC conductivity (S/m), and $\varphi$ represents the self-potential field. The following boundary conditions are applied at infinity (i.e., far from the source current density distribution) $\varphi=0$ (i.e., the potential vanishes to zero far from the source volume). 


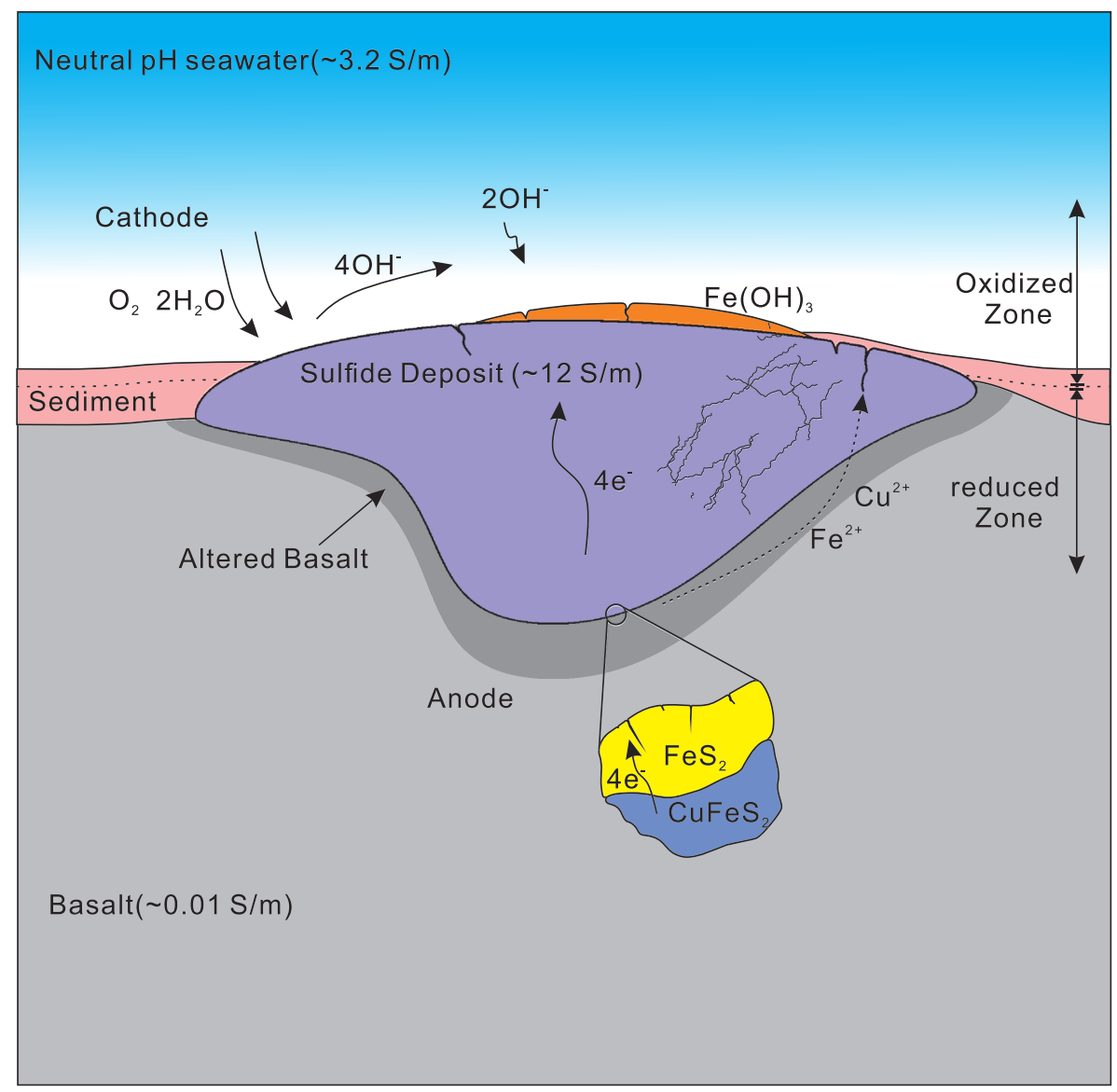

Figure 9. Sketch of the assumed self-potential mechanism at an inactive hydrothermal field. The electrical field is established when the seafloor sulfide crosses an area characterized by a gradient in the redox potential. The corrosion of polymetallic sulfide seems responsible for the current density in the sulfide deposit (massive ore deposit) or portions of it for a fragmented/pervasive but discontinuous ore body. This current density is the source of the observed self-potential signals (partially modified from Fallon et al., 2017).

Using a finite-volume discrete scheme, Equation 6 can be written in matrix form $\mathbf{K} \mathbf{m}=\mathbf{d}$, where $\mathbf{K}$ is the $N \times M$ kernel matrix (numerically computed and dependent on the DC conductivity distribution.), $N$ is the number of observation points (i.e., the number of cells along the two profiles for which the electrical potential has been determined by integrating the electrical field), and $M$ is the number of discretized elements composing the model. In the inverse problem, $\mathbf{J}_{S}$ denotes the unknown source current density vector, $\sigma$ is considered an auxiliary known distribution, and $\varphi$ represents the observations. Therefore, the vector $\mathbf{m}$ denotes the model vector of $M$ elements corresponding to each source current at the discretized elements in the seabed and $\mathbf{d}$ denotes the $N$-dimensional vector corresponding to the self-potential data.

In the inversion problem, we seek to determine the best distribution of the source current density fitting the observation data accounting for their uncertainties. Since the problem is underdetermined, a regularization term should be included in the objective function to ensure the convexity of the objective function. Therefore, we minimize the following objective function:

$$
P^{\alpha}(\boldsymbol{m})=\left\|\mathbf{W}_{d} \Delta \boldsymbol{d}\right\|^{2}+\alpha\left\|\mathbf{W}_{m} \boldsymbol{m}\right\|^{2}
$$

where $\mathbf{W}_{d}$ denotes an $N \times N$ square diagonal weighting matrix determined from the diagonal data covariance matrix (each element is determined from the noise in the self-potential data using the variance at each station), $\boldsymbol{\Delta} \boldsymbol{d}$ denotes the difference between predicted and observed self-potential data, $\mathbf{W}_{m}$ is a roughness operator used to obtain a smooth inversion result, and $\alpha$ is a positive-defined regularization 

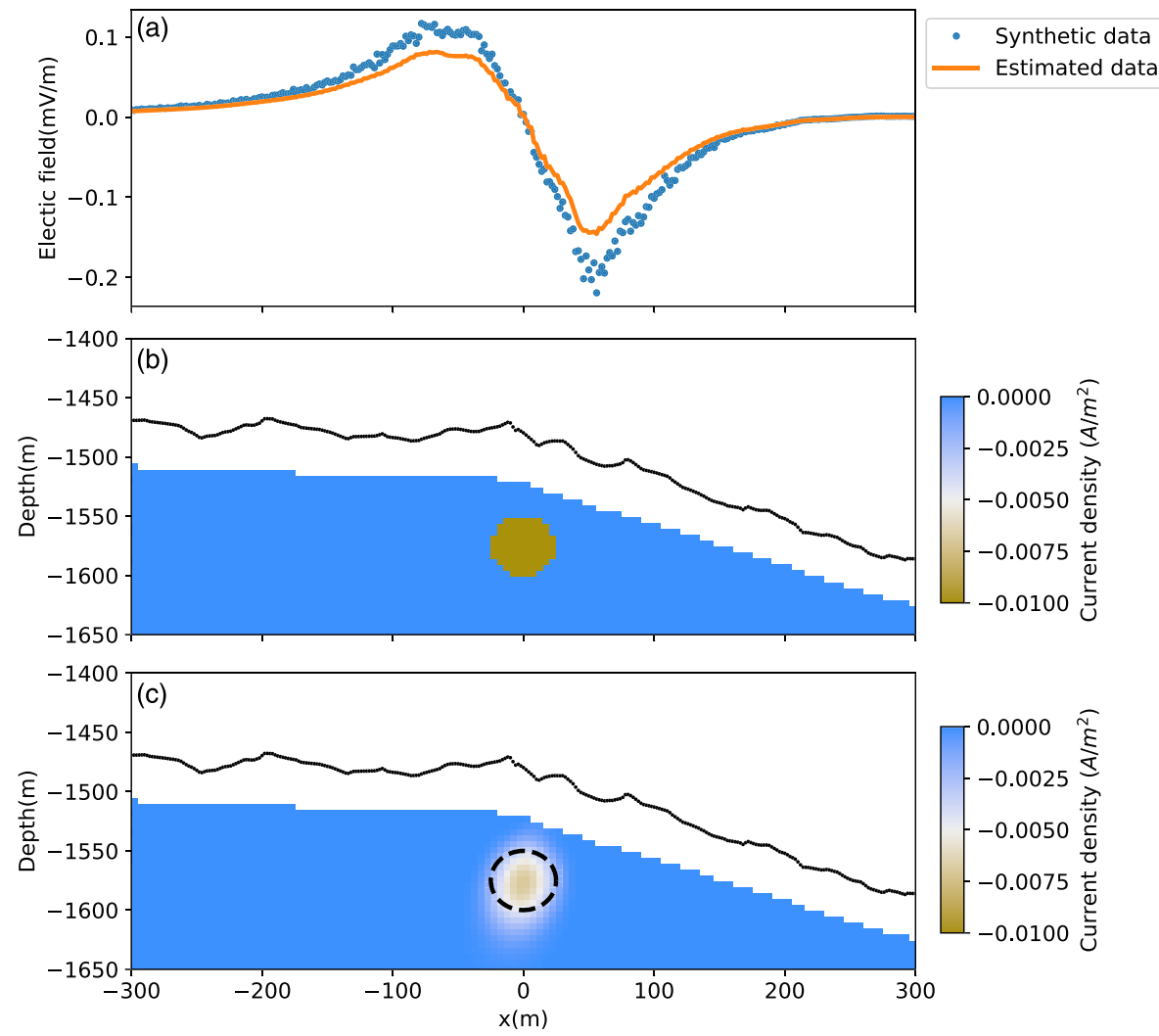

Figure 10. Example of a synthetic model. (a) The synthetic modeling and estimated electrical field data above the seafloor. Five percent white noise is assumed in measured data. (b) Position of vertical source current (represent ore body). A half-space conductivity models with the constant value $1 \mathrm{~S} / \mathrm{m}$ below the seafloor is assumed and the value of seawater conductivity is $3.2 \mathrm{~S} / \mathrm{m}$. (c) Distribution of inverted current density. Black dots in the (b) and (c) denote the observation positions of profile SP01. Black dotted line is the true boundary of the ore body.

parameter. The optimal value of the regularization parameter is determined using the L-curve criterion (see Jardani et al., 2008, for details and benchmarks of this approach).

For inversion, an open-source software package, SimPEG (Cockett et al., 2015; Miller et al., 2018) is used. To test the algorithm, we use the synthetic case shown in Figure 10. A constant conductivity distribution (1 S/m) is assumed below seafloor, and the ore body characterized by a downward vertical current density with a magnitude of $10 \mathrm{~mA} / \mathrm{m}^{2}$ (Figure 10b). The same navigation station of profile SP01 is used to simulate the acquisition of the self-potential signals. Five percent white noise is added to the synthetic observation data. Modeling and predicted data are show in Figure 10a. The inversion of the self-potential data is in good agreement with the true position of the ore body both in terms of the magnitude and the position of the source current density (Figure 10c).

To perform the tomography of the field data, a key issue is to know what conductivity distribution should be used to compute the self-potential anomaly. A pervasive ore body may be resistive because of the polarization of the ore component. The polarization of a pyrite cube is, for instance, shown in Figure 8. Based on laboratory experiments, sandbox experiments, and theoretical consideration regarding the polarization of pervasive sulfide ores, Revil and coworkers (Revil, Abdel, et al., 2015; Revil, Florsch, \& Mao, 2015; Mao \& Revil, 2016) obtained the following formula for the conductivity of a porous material hosting an ore body,

$$
\sigma=\sigma_{b}\left(1-\frac{3}{2} \varphi_{m}\right)
$$

where $\varphi_{m}$ denotes the volume fraction of pyrite and $\sigma_{b}$ is the DC conductivity of the host. Therefore, not only is the ore body not a conductive body under DC conditions (because of its polarization), it is even slightly more resistive than the background. Hence, returning to the issue above (what conductivity 


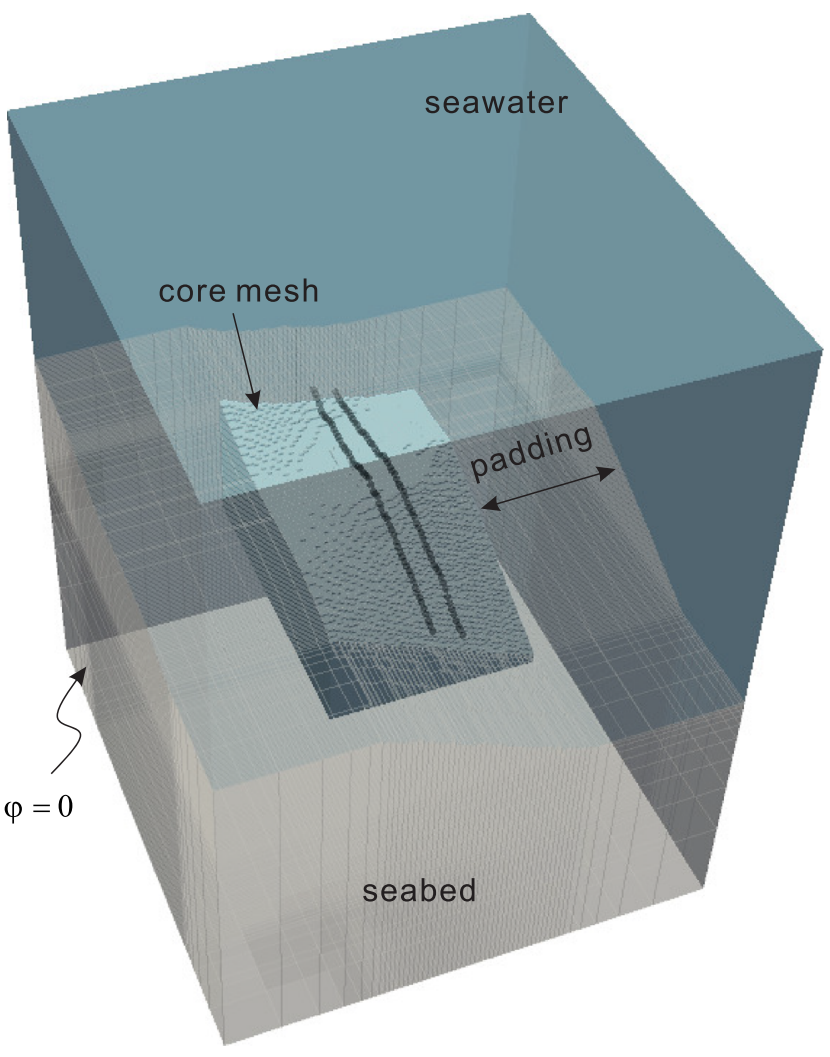

Figure 11. Mesh used for forward and inversion. A 3-D mesh with $10 \times 5 \times 5 \mathrm{~m}$ cell size in the shallowest cells, increasing to $200 \mathrm{~m}$ at the base of the model is constructed. Six layers of padding cells with increasing width are added around the boundaries of the model for a total of 474,810 cells. The electrical (self-)potential goes to 0 at the boundaries. Only the current density below the seafloor is recovered during the inversion. distribution should be considered?), it is safe to use a constant conductivity distribution to compute the self-potential field, which is intrinsically a steady-state field, for pervasive ore bodies. The fact that the ore behaves as a leaking confined semiconductor implies that it is not exactly an insulator either under DC conditions, so we think that a constant conductivity distribution is likely a good trade-off between the distinct effects of polarization and charge leakages. We use a value of $0.01 \mathrm{~S} / \mathrm{m}$ from the laboratory conductivity data of basaltic core samples fully saturated with seawater and with conductivity corrected for the in situ temperature (a $2 \%$ per degree Celsius is applied as a standard temperature correction; see Revil, Qi, et al., 2019; Revil, Razdan, et al., 2019). The in situ conductivity of the seawater close to the seafloor was measured with a CTD sensor. A constant value of approximately 3.2 S/m was obtained. The homogeneous conductivity model assumes that the primary source of the self-potential anomaly is the electric current in the conductive sulfide. Secondary sources associated with the conductivity contrast between the ore and the background can be ignored.

With the assumptions made above, a 3-D conductivity model with the seafloor topography is built to locate the ore body. The forward and inverse modeling of the self-potential data was performed with the mesh shown in Figure 11. A total of 118 measured self-potential data with an average spacing of $10 \mathrm{~m}$ were inverted to obtain the source current density model. We fit the electric field data to root-mean-square (RMS) 1.0 with a $0.02 \mathrm{mV} / \mathrm{m}$ noise floor. Figure 12 shows that the measured electrical field distribution is very well reproduced by the source current density distribution.

Figure 13 shows the distribution of the vertical dipole current density below the seafloor. Minus sign of recovered current density indicates the source of the observed self-potential signals flows downward. In the central portion of the model, the current density anomaly is located at depths between 0 (seafloor) and $65 \mathrm{~m}$. The source depth is estimated at $30 \mathrm{~m}$ below the seafloor where the maximum current density of $3 \mathrm{~mA} / \mathrm{m}^{2}$ occurs. The total strength of dipole moment in the volume is approximately $-300 \mathrm{Am}$, which is comparable to the study by Constable et al. (2018), who, however, used a monopole source distribution, which is unphysical since the total charge density should be zero (Fachin et al., 2012). Indeed, nature is essentially neutral (charge balanced) and a
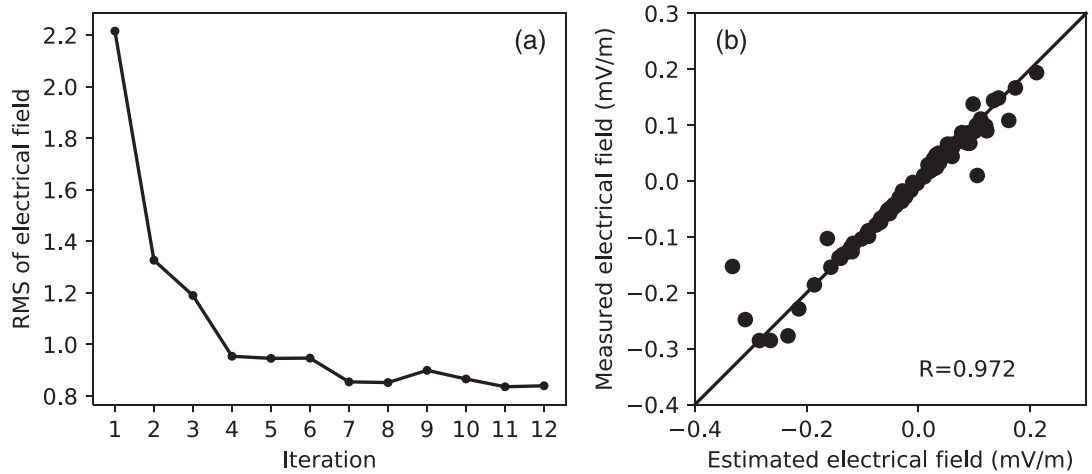

Figure 12. Convergence of the inversion algorithm and fit between the predicted and observed data. (a) Root-meansquare (RMS) of the data misfit (for the observed electrical field with 5\% noise) as a function of the number of iterations used to minimize the cost function. (b) Measured versus estimated observed electrical field for the last iteration when convergence is reached. 


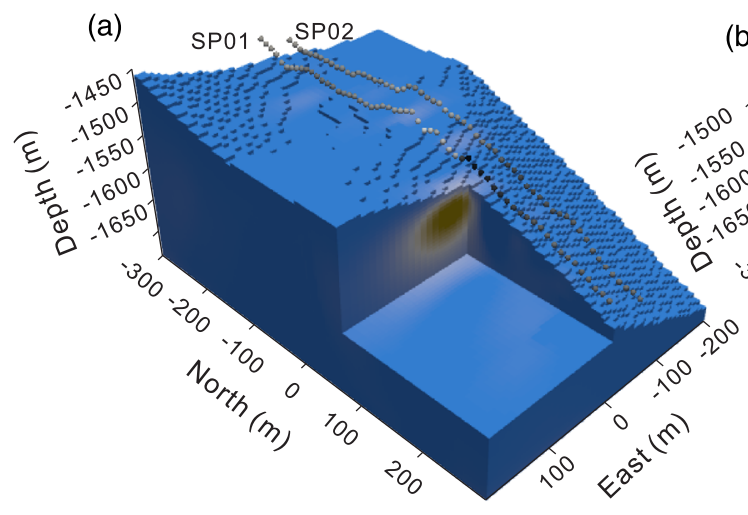

(b)

(c)

(d)

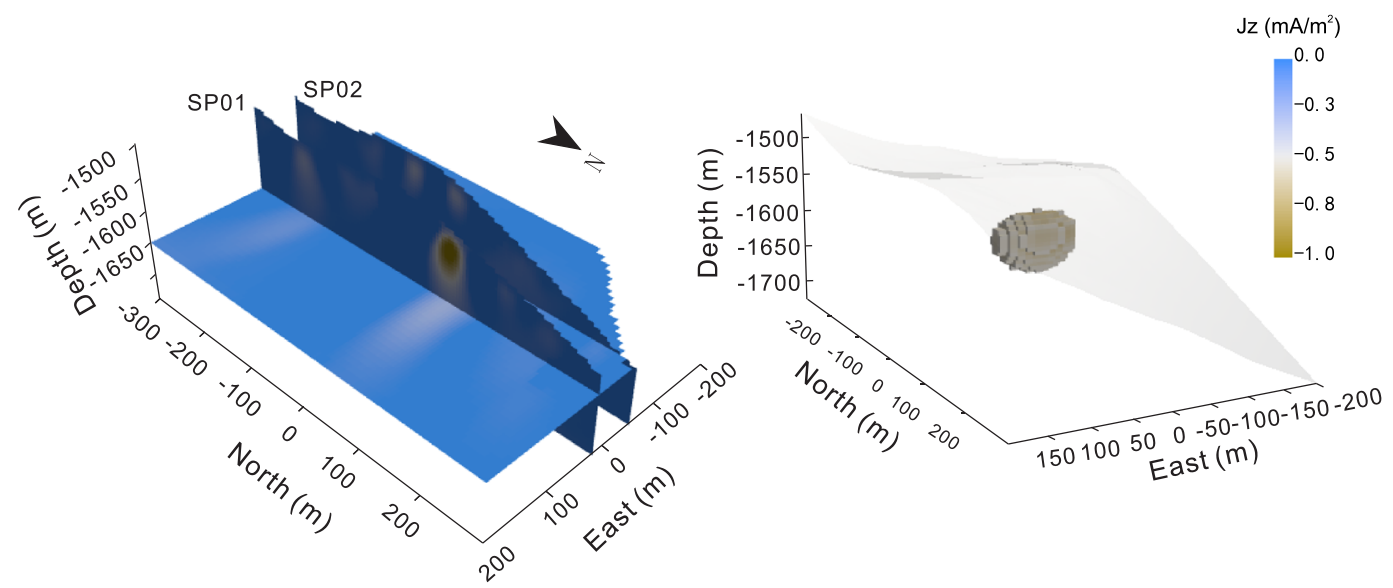

Figure 13. Inversion of the self-potential data in terms of the source current density distribution. (a) Inverted source current model distribution; black dots are the positions of electrode in the seawater. (b) Cross sections along eastwest with $y=0 \mathrm{~m}$ and $y=70 \mathrm{~m}$. (c). Cross section of inverted current density right below the profile SP01 and SP02. (d). Inferred ore body from inverted data (domain where the magnitude of current density lower than $-0.5 \mathrm{~mA} / \mathrm{m}^{2}$ ). Note that the lateral extension of the ore body is limited by the self-potential data set acquired only along two parallel lines.

geobattery can only generate charge separation. This is why a multipole decomposition of the source is necessary to explain a dipolar character in the far field. We obtain a 3-D volume of current density distribution and much of the detailed structure of the ore seems to be recovered (Figure 13d). The shape of the current density at depth indicates a sulfide deposit with a lens shape, which is a typical inner structure of sulfide deposits at basalt hosted hydrothermal fields (see, for instance, Murton et al., 2019).

In addition, current density anomalies from inversion obviously show 3-D effects on the measured electrical field. Since the two self-potential profiles are parallel along the south-north direction, the boundaries of the sulfide deposit along the SN direction are well determined, while the boundaries along the normal (i.e., EW direction) are poorly constrained. Additional information in the EW direction is needed to determine the exact distribution of this sulfide deposit in this direction. Despite the limited observations, we demonstrate the ability of self-potential tomography to delineate three-dimensional ore body boundaries.

\subsection{Influence of the Conductivity Distribution}

Some massive ore deposits can be conductive (Ishizu et al., 2019), and therefore, it is possible to test the effect of the conductivity structure on the localization of the causative source of the observed self-potential data. Here, we performed a 2-D sensitivity analysis to show this point. The result is shown in Figure 14. From these simulations, the conductivity of the ore body is important to better constrain the location of the 

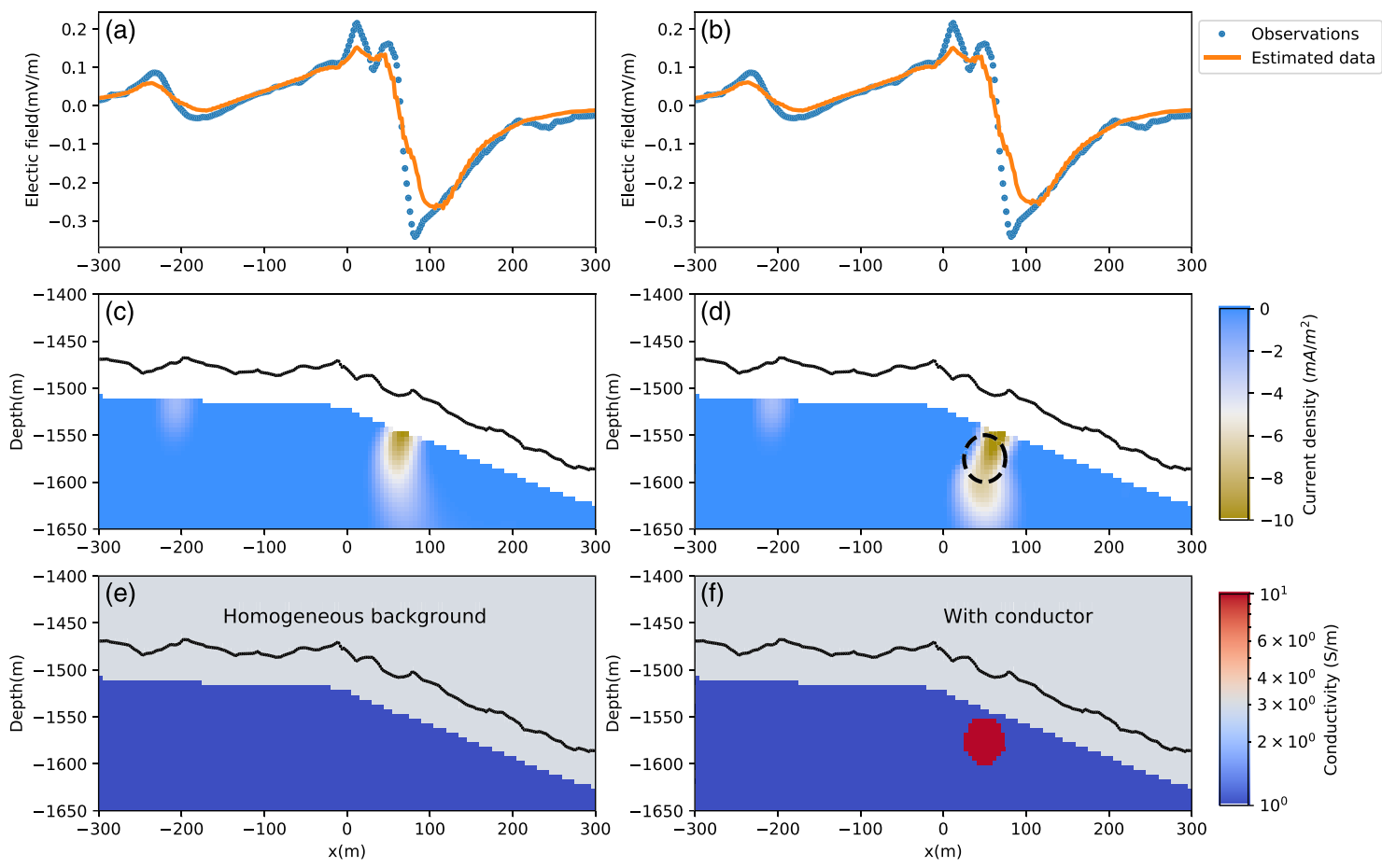

Figure 14. (a-f) Influence of the conductivity structure upon the localization of the self-potential sources. On the right panels, the conductivity anomaly is $10 \mathrm{~S} / \mathrm{m}$. Black dotted line in (d) denotes the position of conductor.

source current density. The conductivity distribution of massive deposits may therefore be an important component of self-potential inversion and should not be overlooked. Based on recent developments in marine electrical conductivity and IP tomography, we can use a combination of methods to better locate and characterize massive and pervasive ore deposits in the future.

\subsection{Self-Potential Method as a Tool to Characterize Sulfide Deposits}

Video surveys and drilling reveal that most massive sulfide deposits in the study area are covered by pelagic and/or hydrothermal sediments with a maximum thickness of up to $5 \mathrm{~m}$. This is characteristic of the vast majority of inactive hydrothermal fields on mid-ocean ridges (Liao et al., 2018; Murton et al., 2019). These buried mineral deposits cannot be detected by near seafloor cameras and plume detection used in active vent locating. Chemical gradients and redox reactions around extinct mineral deposits generate an electrical current, which can be remotely detected by self-potential measurements in the seawater.

Notably, hydrothermal circulation under the seafloor can also distort the measured self-potential signals through the existence of electrokinetic effects (Richards et al., 2010). These electrokinetic effects are assumed however to be much smaller than the self-potential signals associated with sulfide deposits. For a resource assessment, it is essential to determine the three-dimensional extent of the sulfide deposits. Although the active source electromagnetic data can reveal the high-resolution inner structure of the subseafloor (e.g., Gehrmann et al., 2019; Ishizu et al., 2019; Tao et al., 2013), self-potential signals offer a simpler alternative for obtaining quantitative information regarding the extent of sulfide bodies in the initial stage of SMS exploration.

\section{Conclusion}

We conducted a marine self-potential survey using a deep-towed horizontal electrode array. Two $1 \mathrm{~km}$ long parallel profiles with a $100 \mathrm{~m}$ line distance were collected over the Yuhuang seamount, an inactive hydrothermal field located at the SWIR. The three components of the electrical field were recorded. The maximum magnitude amplitude of the electrical field reached $0.8 \mathrm{mV} / \mathrm{m}$, and this disturbance was 
observed over a distance of $500 \mathrm{~m}$ along the two profiles. The measurements were made at an average height of $40 \mathrm{~m}$ above the seafloor. The integration of the electrical field yields a negative self-potential anomaly with a minimum of -20 to $-27 \mathrm{mV}$ associated with a conductive sulfide deposit; this is a rather strong self-potential anomaly if we account for the high conductivity of the sea water (approximately 3.2 S/m). The existence of the ore deposit associated with this anomaly was independently confirmed by near-surface sampling and drilling. The geology and petrophysical properties reveal that the corrosion of extinct polymetallic sulfides can produce a natural electrical (source) current even in the absence of hydrothermal activities. The inversion of the measured self-potential anomaly reveals the spatial extent of the sulfide body at depths below the two profiles. For this purpose, we have assumed here a constant electrical conductivity distribution below the seafloor, which is justified by the small effect of the ore on the overall DC conductivity of the material. This small conductivity effect is expected because of the full polarization of the ore in DC conduction as recognized in the literature. Our approach based on self-potential tomography can be used for resource assessments. Our experiment demonstrates that the self-potential method is a useful method to explore and characterize seafloor sulfides at inactive hydrothermal fields. Future analysis must however combine IP with the inversion of the self-potential data to better quantify such valuable resources.

\section{Data Availability Statement}

All the data used to generate the figures can be obtained by connecting the corresponding author (C. Tao. taochunhuimail@163.com). The data are available on PANGAEA (https://doi.org/10.1594/PANGAEA. 922345).

\section{Acknowledgments}

Thanks to China University of Geosciences (Beijing) for providing the data acquisition device and electrodes. This work was supported by National Key R\&D Program of China under contract Nos. 2018YFC0309901, 2017YFC0306803, 2017YFC0306603, 2017YFC0306203 and China Ocean Mineral Resources R \& D Association (COMRA), Project (DY135-S1-1-01,07) We thank the Editor, Douglas Schmitt, the Associate Editor, Max Moorkamp, and the two referees, Dr. Hendrik Müller and an anonymous reviewer, for their fruitful comments that have helped us to forge a better manuscript.

\section{References}

Abdulsamad, F., Revil, A., Soueid Ahmed, A., Coperey, A., Karaoulis, M., Nicaise, S., \& Peyras, L. (2019). Induced polarization tomography applied to the detection and the monitoring of leaks in embankments. Engineering Geology, 254, 89-101. https://doi.org/10.1016/j. enggeo.2019.04.001

Archie, G.E. (1942). The electrical resistivity log as an aid in determining some reservoir characteristics. SPE-942054-G. https://doi.org/ 10.2118/942054-G

Beltenev, V., Ivanov, V., Rozhdestvenskaya, I., Cherkashov, G., Stepanova, T., Shilov, V., \& Pertsev, A. (2008). New data about hydrothermal fields on the Mid-Atlantic Ridge between $11-14^{\circ} \mathrm{N}$ : 32nd Cruise of R/V Professor Logatchev. Geochemistry Geophysics Geosystems, 10, 1029.

Chen, K., Deng, M., Luo, X., \& Wu, Z. (2018). A micro ocean bottom E-field receiver. Geophysics, 82(5), E233-E241.

Cherkashov, G., Poroshina, I., Stepanova, T. V., Ivanov, V. N., Beltenev, V. E., Lazareva, L. I., \& Kuznetsov, V. (2010). Seafloor massive sulfides from the northern equatorial mid-Atlantic ridge: New discoveries and perspectives. Marine Georesources \& Geotechnology, 28(3), 222-239. https://doi.org/10.1080/1064119X.2010.483308

Cockett, R., Kang, S., Heagy, L. J., Pidlisecky, A., \& Oldenburg, D. W. (2015). SimPEG: An open source framework for simulation and gradient based parameter estimation in geophysical applications. Computers and Geosciences, 85, 142-154. https://doi.org/10.1016/j. cageo.2015.09.015

Constable, S., Kowalczyk, P., \& Bloomer, S. (2018). Measuring marine self-potential using an autonomous underwater vehicle. Geophysical Journal International, 215(1), 49-60. https://doi.org/10.1093/gii/ggy263

Corwin, R. F. (1976). Offshore use of the self-potential method. Geophysical Prospecting, 24(1), 79-90. https://doi.org/10.1111/j.13652478.1976.tb00386.x

Cumella, S. P., Woodruff, W., \& Revil, A. (2017). Piceance Basin Mesaverde anomalous self potential response-Identification of capillary seals in a basin-centered gas accumulation. AAPG Bulletin, 101(01), 19-37. https://doi.org/10.1306/06201615130

Fachin, S. J. S., Abreu, E. L., Mendonça, C. A., Revil, A., Novaes, G. C., \& Vasconcelos, S. S. (2012). Self-potential signals from an analog biogeobattery model. Geophysics, 77(4), EN29-EN37. https://doi.org/10.1190/GEO2011-0352.1

Fallon, E. K., Petersen, S., Brooker, R. A., \& Scott, T. B. (2017). Oxidative dissolution of hydrothermal mixed-sulphide ore: An assessment of current knowledge in relation to seafloor massive sulphide mining. Ore Geology Reviews, 86, 309-337. https://doi.org/10.1016/j. oregeorev.2017.02.028

Gehrmann, R., North, L. A., Graber, S., Szitkar, F., Petersen, S., Minshull, T. A., \& Murton, B. J. (2019). Marine mineral exploration with controlled source electromagnetics at the TAG hydrothermal field, $26^{\circ} \mathrm{N}$ mid-Atlantic ridge. Geophysical Research Letters, $46,5808-5816$. https://doi.org/10.1029/2019GL082928

Grech, R. T., Cassar, J., Muscat, K. P., Camilleri, S. G., Fabri, M., Zervakis, P., et al. (2008). Review on solving the inverse problem in EEG source analysis. Journal of Neuroengineering and Rehabilitation, 5(1), 25-25. https://doi.org/10.1186/1743-0003-5-25

Haas, A. K., Revil, A., Karaoulis, M., Frash, L., Hampton, J., Gutierrez, M., \& Mooney, M. (2013). Electrical potential source localization reveals a borehole leak during hydraulic fracturing. Geophysics, 78(2), D93-D113. https://doi.org/10.1190/GEO2012-0388.1

Hannington, M. D., Jamieson, J., Monecke, T., Petersen, S., \& Beaulieu, S. E. (2011). The abundance of seafloor massive sulfide deposits. Geology, 39(12), 1155-1158. https://doi.org/10.1130/G32468.1

Haroon, A., Holz, S., Gehrmann, R., Attias, E., Jegen, M., Minshull, T. A., \& Murton, B. J. (2018). Marine dipole-dipole controlled source electromagnetic and coincident-loop transient electromagnetic experiments to detect seafloor massive sulfides: Effects of three-dimensional bathymetry. Geophysical Journal International, 215(3), 2156-2171. https://doi.org/10.1093/gji/ggy398

Heinson, G., White, A., Robinson, D., \& Fathianpour, N. (2005). Marine self-potential gradient exploration of the continental margin. Geophysics, 70(5), G109-G118. https://doi.org/10.1190/1.2057981 
Hördt, A., Bairlein, K., Spagnoli, G., Jegen, M., Hannington, M. D., Petersen, S., \& Laurila, T. E. (2016). Induced polarization of seafloor massive sulfides. In International workshop on induced polarization (pp. 6-8 June, 2016). Aarhus, Denmark: University of Aarhus. https://doi.org/10.1016/j.cageo.2015.09.015

Ishido, T., \& Mizutani, H. (1981). Experimental and theoretical basis of electrokinetic phenomena in rock-water systems and its application to geophysics. Journal of Geophysical Research, 86, 1763-1775. https://doi.org/10.1029/JB086iB03p01763

Ishizu, K., Goto, T., Ohta, Y., Kasaya, T., Iwamoto, H., Vachiratienchai, C., \& Koike, K. (2019). Internal structure of a seafloor massive sulfide deposit by electrical resistivity tomography, Okinawa Trough. Geophysical Research Letters, 46, 11,025-11,034. https://doi.org/ 10.1029/2019GL083749

Jardani, A., Revil, A., Bolève, A., \& Dupont, J. P. (2008). Three-dimensional inversion of self-potential data used to constrain the pattern of groundwater flow in geothermal fields. Journal of Geophysical Research, 113, B09204. https://doi.org/10.1029/2007JB005302

Jones, E. J. W. (1999). Marine geophysics. Hoboken (New Jersey): Wiley.

Karaoulis, M., Revil, A., \& Mao, D. (2014). Localization of a coal seam fire using combined self-potential and resistivity data. International Journal of Coal Geology, 128-129, 109-118. https://doi.org/10.1016/j.coal.2014.04.011

Kawada, Y., \& Kasaya, T. (2017). Marine self-potential survey for exploring seafloor hydrothermal ore deposits. Scientific Reports, 7(1), 1-12. https://doi.org/10.1038/s41598-017-13920-0

Kawada, Y., \& Kasaya, T. (2018). Self-potential mapping using an autonomous underwater vehicle for the Sunrise deposit, Izu-Ogsasawara arc, southern Japan. Earth, Planets and Space, 70(1), 142.

Liao, S., Tao, C., Li, H., Barriga, F. J., Liang, J., Yang, W., \& Zhu, C. (2018). Bulk geochemistry, sulfur isotope characteristics of the Yuhuang-1 hydrothermal field on the ultraslow-spreading Southwest Indian Ridge. Ore Geology Reviews, 96, 13-27. https://doi.org/ 10.1016/j.oregeorev.2018.04.007

Lipton, I. (2008). Mineral resource estimate Solwara 1 project Bismarck Sea Papua New Guinea for Nautilus Minerals Inc. Technical Report Canadian.

Mao, D., \& Revil, A. (2016). Induced polarization response of porous media with metallic particles-Part 3. A new approach to time-domain induced polarization tomography. Geophysics, 81(4), D345-D357. https://doi.org/10.1190/geo2015-0283.1

Miller, C. A., Kang, S. G., Fournier, D., \& Hill, G. (2018). Distribution of vapor and condensate in a hydrothermal system: Insights from self-potential inversion at Mount Tongariro, New Zealand. Geophysical Research Letters, 45, 8190-8198. https://doi.org/10.1029/ 2018GL078780

Müller, H., Schwalenberg, K., Reeck, K., Barckhausen, U., Schwarz-Schampera, U., Hilgenfeldt, C., \& von Dobeneck, T. (2018). Mapping seafloor massive sulfides with the Golden Eye frequency-domain EM profiler. First Break, 36(10), 61-67.

Murton, B. J., Lehrmann, B., Dutrieux, A., Martins, S., La Iglesia, A. G., Stobbs, I., \& Petersen, S. (2019). Geological fate of seafloor massive sulphides at the TAG hydrothermal field (Mid-Atlantic Ridge). Ore Geology Reviews, 107, 903-925. https://doi.org/10.1016/j. oregeorev.2019.03.005

Naudet, V., \& Revil, A. (2005). A sandbox experiment to investigate bacteria-mediated redox processes on self-potential signals. Geophysical Research Letters, 32, L11405. https://doi.org/10.1029/2005GL022735

Nielsen, L. P., Risgaard-Petersen, N., Fossing, H., Christensen, P. B., \& Sayama, M. (2010). Electric currents couple spatially separated biogeochemical processes in marine sediment. Nature, 463(7284), 1071-1074. https://doi.org/10.1038/nature08790

Pridmore, D. F., \& Shuey, R. T. (1976). The electrical resistivity of galena, pyrite, and chalcopyrite. American Mineralogist, 61, 248-259.

Revil, A., Abdel, G. Z. A., Atekwana, E. A., Mao, D., \& Florsch, N. (2015). Induced polarization response of porous media with metallic particles-Part 2. Comparison with a broad database of experimental data. Geophysics, 80(5), D539-D552. https://doi.org/10.1190/ GEO2014-0578.1

Revil, A., Florsch, N., \& Mao, D. (2015). Induced polarization response of porous media with metallic particles-Part 1: A theory for disseminated semiconductors. Geophysics, 80(5), D525-D538. https://doi.org/10.1190/GEO2014-0577.1

Revil, A., \& Jardani, A. (2013). The self-potential method. Theory and Applications in environmental geosciences. Cambrdige: Cambridge University Press. https://doi.org/10.1017/CBO9781139094252

Revil, A., Karaoulis, M., Johnson, T., \& Kemna, A. (2012). Review: Some low-frequency electrical methods for subsurface characterization and monitoring in hydrogeology. Hydrogeology Journal, 20(4), 617-658. https://doi.org/10.1007/s10040-011-0819-x

Revil, A., Karaoulis, M., Srivastava, S., \& Byrdina, S. (2013). Thermoelectric self-potential and resistivity data localize the burning front of underground coal fires. Geophysics, 78(5), B259-B273. https://doi.org/10.1190/geo2013-0013.1

Revil, A., Mendonça, C. A., Atekwana, E., Kulessa, B., Hubbard, S. S., \& Bolhen, K. (2010). Understanding biogeobatteries: Where geophysics meets microbiology. Journal of Geophysical Research, 115, G00G02. https://doi.org/10.1029/2009JG001065

Revil, A., Qi, Y., Ghorbani, A., Coperey, A., Soueid, A., Finizola, A., \& Ricci, T. (2019). Induced polarization of volcanic rocks. 3. Imaging clay cap properties in geothermal fields. Geophysical Journal International, 218(2), 1398-1427. https://doi.org/10.1093/gji/ ggz207

Revil, A., Razdan, M., Julien, S., Coperey, A., Mao, D., Abdulsamad, F., et al. (2019). Induced polarization response of porous media with metallic particles-Part 9. Influence of permafrost, Geophysics, 84(5), E337-E355. https://doi.org/10.1190/geo2019-0013.1

Richards, K., Revil, A., Jardani, A., Henderson, F., Batzle, M., \& Haas, A. (2010). Pattern of shallow ground water flow at Mount Princeton Hot Springs, Colorado, using geoelectrical methods. Journal of Volcanology and Geothermal Research, 198(1-2), 217-232. https://doi.org/ 10.1016/j.jvolgeores.2010.09.001

Rittgers, J. B., Revil, A., Karaoulis, M., Mooney, M. A., Slater, L. D., \& Atekwana, E. A. (2013). Self-potential signals generated by the corrosion of buried metallic objects with application to contaminant plumes. Geophysics, 78(5), EN65-EN82. https://doi.org/10.1190/ GEO2013-0033.1

Safipour, R., Hölz, S., Halbach, J., Jegen, M., Petersen, S., \& Swidinsky, A. (2017). A self-potential investigation of submarine massive sulfides: Palinuro Seamount, Tyrrhenian Sea. Geophysics, 82(6), A51-A56. https://doi.org/10.1190/geo2017-0237.1

Sato, M., \& Mooney, H. M. (1960). The electrochemical mechanism of sulfide self-potentials. Geophysics, 25(1), 226-249. https://doi.org/ $10.1190 / 1.1438689$

Sato, S., Goto, T., Kasaya, T., Kawada, Y., Iwamoto, H., \& Kitada, K. (2017). Noise reduction method of marine spontaneous electric field data using independent component analysis. Butsuri-tansa (geophysical Exploration), 70, 42-55. https://doi.org/10.3124/segj.70.42

Schwalenberg, K., Müller, H., Engels, M., Rippe, D., \& Gehrmann, R. A. S. (2016). Marine electromagnetic and electrical case studies of seafloor massive sulfide systems and submarine gas hydrates. In Near Surface Geoscience 2016-Second Applied Shallow Marine Geophysics Conference.

Tao, C., Lin, J., Guo, S., Chen, Y. J., Wu, G., Han, X., \& Zhu, J. (2012). First active hydrothermal vents on an ultraslow-spreading center: Southwest Indian Ridge. Geology, 40(1), 47-50. https://doi.org/10.1130/G32389.1 
Tao, C., Xiong, W., Xi, Z., Deng, X., \& Xu, Y. (2013). TEM investigations of South Atlantic Ridge $13.2^{\circ}$ S hydrothermal area. Acto Oceanologica Sinica, 32(12), 68-74. https://doi.org/10.1007/s13131-013-0392-3

Von Herzen, R. P., Kirklin, J., \& Becker, K. (1996). Geoelectrical measurements at the TAG Hydrothermal Mound. Geophysical Research Letters, 23(23), 3451-3454. https://doi.org/10.1029/96GL02077

Yamamoto, M., Nakamura, R., \& Takai, K. (2018). Deep-sea hydrothermal fields as natural power plants. ChemElectroChem, 5(16), 2162-2166. https://doi.org/10.1002/celc.201800394 